\title{
Food Redistribution in the Nordic Region
}

Phase II: Identification of best practice models for enhanced food redistribution

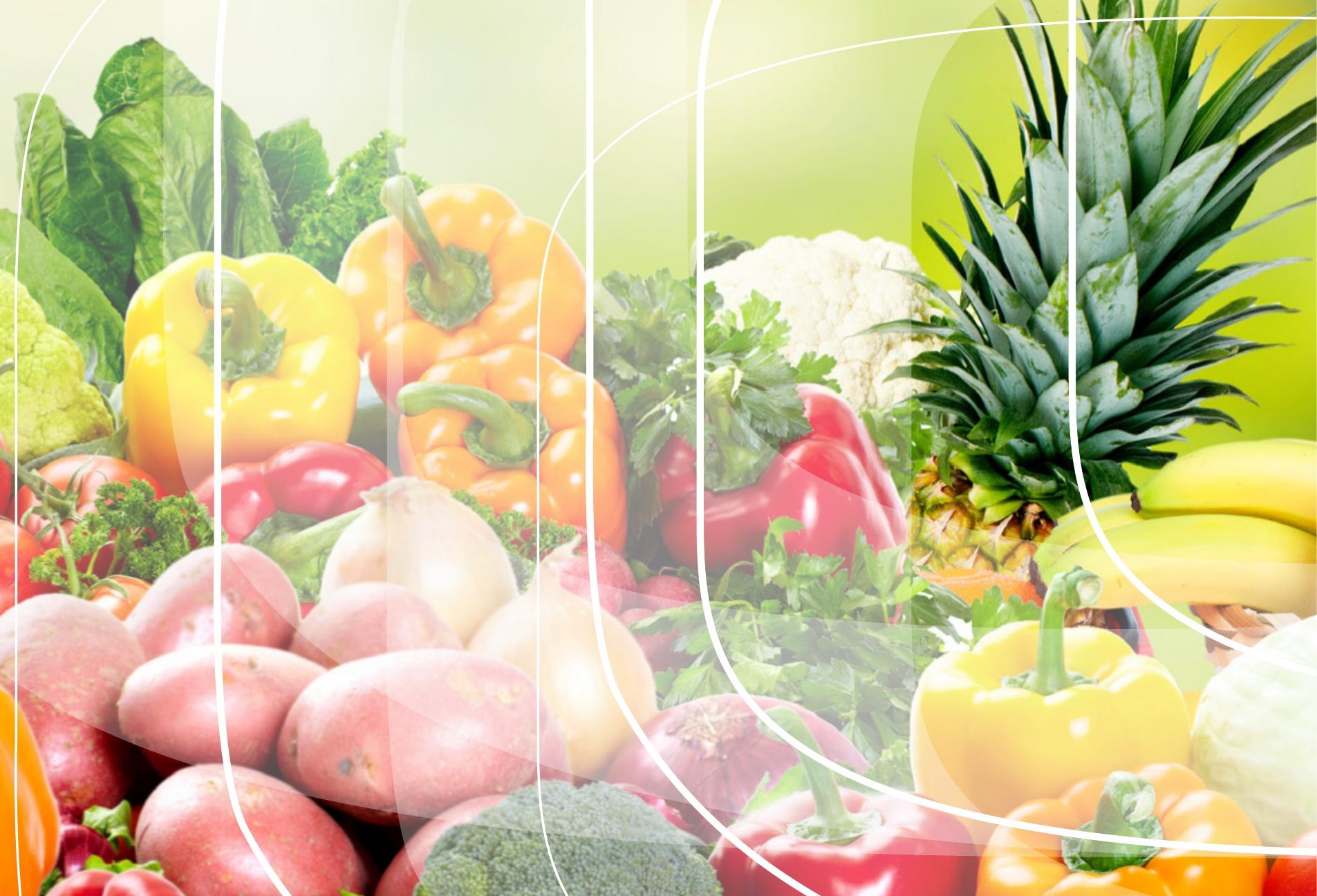







\section{Food Redistribution in the Nordic Region}

Phase II: Identification of best practice models for enhanced food redistribution

Irmelin Gram-Hanssen, Ole Jørgen Hanssen, Johan Hultén, Kirsi Silvennoinen, Mads Werge, Åsa Stenmarck and

Ane Kirstine Aare 
Food Redistribution in the Nordic Region

Phase II: Identification of best practice models for enhanced food redistribution

Irmelin Gram-Hanssen, Ole Jørgen Hanssen, Johan Hultén, Kirsi Silvennoinen, Mads Werge Åsa Stenmarck and Ane Kirstine Aare

ISBN 978-92-893-4447-0 (PRINT)

ISBN 978-92-893-4449-4 (PDF)

ISBN 978-92-893-4448-7 (EPUB)

http://dx.doi.org/10.6027/TN2016-502

TemaNord 2016:502

ISSN 0908-6692

(C) Nordic Council of Ministers 2016

Layout: Hanne Lebech

Cover photo: ImageSelect

Print: Rosendahls-Schultz Grafisk

Printed in Denmark

This publication has been published with financial support by the Nordic Council of Ministers. However, the contents of this publication do not necessarily reflect the views, policies or recommendations of the Nordic Council of Ministers.

www.norden.org/nordpub

Nordic co-operation

Nordic co-operation is one of the world's most extensive forms of regional collaboration, involving Denmark, Finland, Iceland, Norway, Sweden, and the Faroe Islands, Greenland, and Åland.

Nordic co-operation has firm traditions in politics, the economy, and culture. It plays an important role in European and international collaboration, and aims at creating a strong Nordic community in a strong Europe.

Nordic co-operation seeks to safeguard Nordic and regional interests and principles in the global community. Common Nordic values help the region solidify its position as one of the world's most innovative and competitive.

Nordic Council of Ministers

Ved Stranden 18

DK-1061 Copenhagen K

Phone (+45) 33960200

www.norden.org 


\section{Contents}

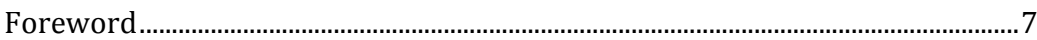

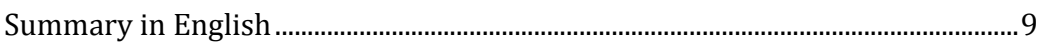

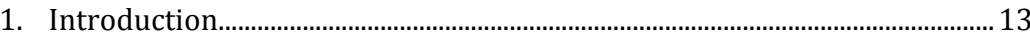

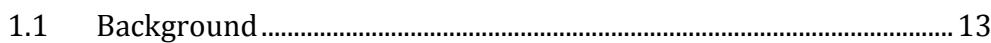

1.2 Main findings from phase I....................................................................15

1.3 Relevant studies ................................................................................ 17

2. Goal and scope of the project ..................................................................... 19

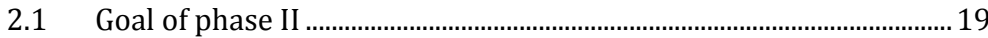

2.2 Models for redistribution ........................................................................19

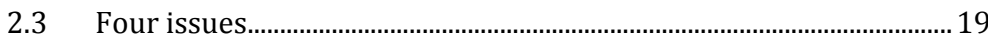

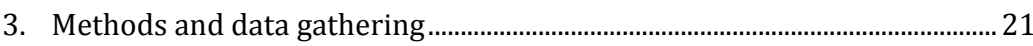

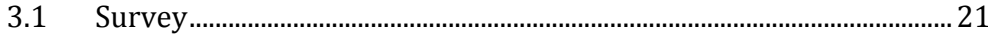

3.2 Workshops ........................................................................................... 22

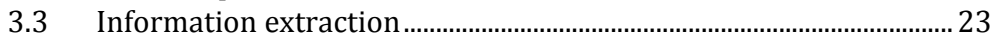

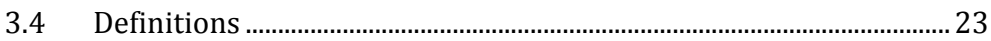

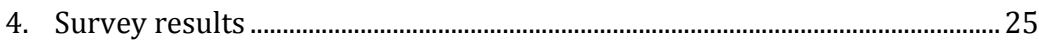

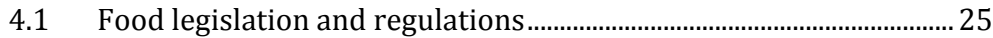

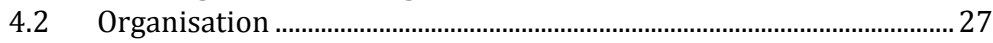

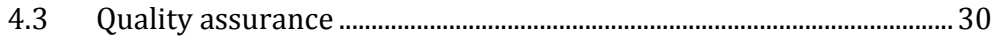

4.4 Registration and tracing of food............................................................. 30

5. Legislation and regulations: Existing laws and "best practice" guidelines

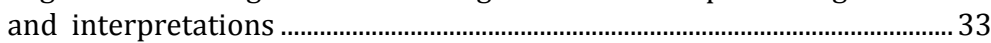

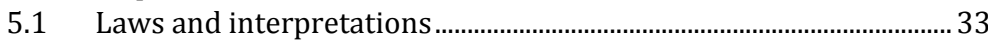

5.2 Legal challenges and possible solutions ................................................ 35

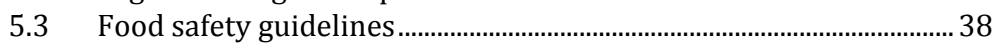

5.4 Extended producer responsibility ........................................................ 41

5.5 Recommendations................................................................................. 42

6. Organisation: Developing sustainable business models for food

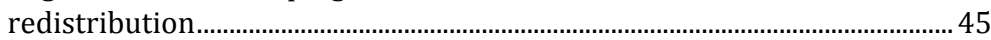

6.1 Different organisational set-ups........................................................... 45

6.2 Organisational challenges ................................................................. 48

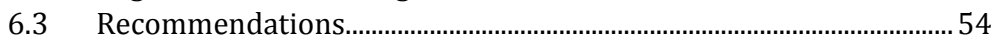

7. Quality assurance: Developing a common platform for quality systems 63

7.1 Reasons for having a system for quality assurance ............................ 63

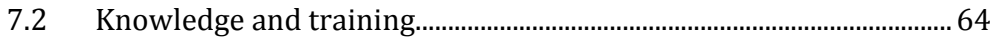

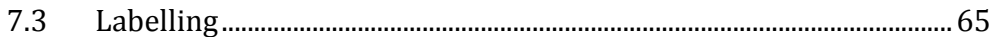

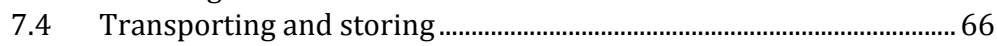

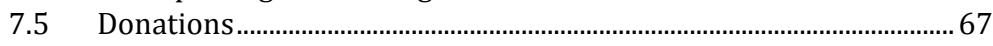

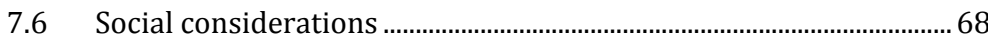

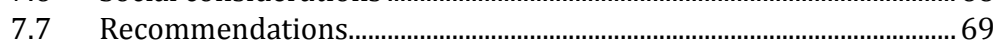


8. Registration and tracing: Systems for traceability throughout the

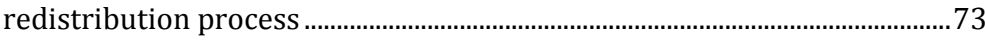

8.1 Reasons for having a system for registration and tracing ...............73

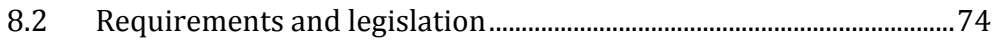

8.3 Current systems for tracing and registration of food used in

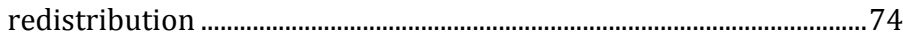

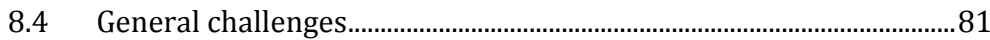

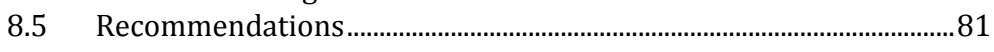

9. Main recommendations ..............................................................................85

9.1 Main recommendations for redistribution and food-serving

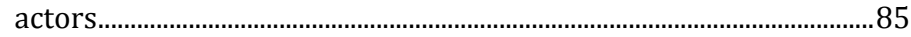

9.2 Main recommendations for donors........................................................... 87

9.3 Main recommendations for authorities.................................................. 89

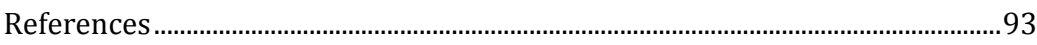

Sammendrag på dansk ........................................................................................97

Appendices........................................................................................................... 101

Appendix I: Participating organisations and individuals............................. 101

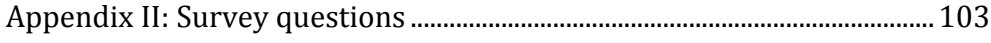




\section{Foreword}

Food waste reduction is an area of growing importance among the Nordic governments as well as at the EU level. The Nordic Council of Ministers has published several reports in recent years as part of the Green Growth Program, showing the amounts of food wasted and proposing technical and organizational solutions to the problems of food waste.

Based on previous work done in the Nordic Food Redistribution Project, this report investigates best practice models among donors, receivers and authorities and proposes concrete steps towards safe and comprehensive systems for food redistribution through food banks and direct redistribution. The report thereby points to the feasibility of redistribution as a food waste reduction measure in the Nordic countries. The report presents actors-specific recommendations that are likely to enhance food redistribution at the local, regional and national levels.

A third and final project phase will focus on implementing some of these systems into local contexts in collaboration with national actors in the Nordic countries so that these can act as frontrunners and sources of inspiration throughout the Nordics and beyond.

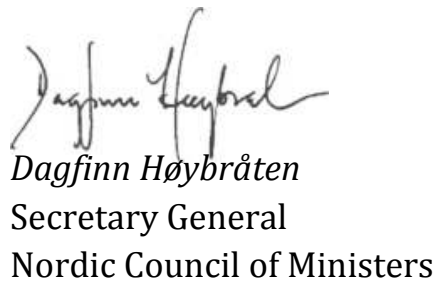





\section{Summary in English}

This report summarizes experiences and results from Phase II of the Nordic Food Redistribution Project. The project was initiated by the Nordic Council of Ministers as part of the Nordic Prime Ministers' green growth initiative, "The Nordic Region - leading in green growth", with budget from the Food and Agriculture program.

The project focuses on how food redistribution activities are organised and conducted in the Nordic countries as well as how to enhance such activities while ensuring food safety. In this project, food redistribution is primarily viewed in the light of environmental concerns, since food production and the related food waste has a significant environmental footprint. However, with additional considerable social and economic implications, food redistribution can be seen as a way to enhance overall sustainable development - in the Nordic countries as well as globally.

In phase I, the main barriers and possible solutions for food redistribution were identified. In phase II, the goal has been to further investigate these issues and establish "best practices" for the further enhancement of current and future activities. One central issue is how to transform current systems, which are largely based on volunteers and have a fragile financial structure, into sustainable business models that are capable of greatly reducing food waste in the Nordic countries.

Based on the findings from phase I, phase II has focused on the following four activities:

- Evaluating the national regulatory system for direct food redistribution combined with central redistribution and describing how the regulatory systems function in each country as well as giving input to "good practise models".

- Developing a framework for how local and centralized food redistribution can be organised where food banks can take the role as food redistribution centres.

- Developing platforms for quality improvement and assurance systems for food redistribution in the Nordic countries.

- Developing systems for registration and tracing of food. 
These activities have been carried out in the four Nordic countries (Denmark, Finland, Norway and Sweden), led by national research institutions in collaboration with national food safety authorities as well as redistribution and food-serving actors. Input from all relevant actors have been facilitated through two workshops during 2015 in Oslo and Gothenburg respectively. The research institutions are responsible for the final recommendations.

Local and national contexts vary, and therefore there is no "one size fits all" in redistribution. Recommendations presented in this report should therefore be evaluated in light of local conditions.

The main recommendations are directed at three central actor groups and can be summarized as follows:

\section{Redistribution and food-serving actors (including food banks, charity organisations and other users of surplus food)}

- Establish a national/regional platform or systems operator to ensure collaboration between actors involved in redistribution and efficient use of available resources.

- Develop guidelines for redistribution practices, including quality assurance and registration to ensure food safety and build trust with donors as well as the public.

- Secure sustainable funding of redistribution activities by defining services provided and communicating results.

\section{Donors (including all food business operators in possession of surplus food that are or could be involved in food donation)}

- Incorporate food donation as part of Corporate Social Responsibility strategy to be on the forefront of increasing consumer expectations and future legal requirement.

- Develop guidelines for donation practices in collaboration with redistribution actors and authorities in order to ensure food safety and reduce unnecessary food waste in the redistribution chain.

- Contribute to the operation of redistribution activities through payment relative to the services provided by redistribution actors, e.g. membership fees or payment per delivery/pick-up. 
Authorities (including social, environmental, and waste management authorities at the local, regional and national level)

- Prioritize food redistribution in the waste hierarchy and view food redistribution as a tool to reduce the environmental impact of the food industry, enhance social security for the socially disadvantaged as well as reduce food waste related management costs for businesses and local authorities.

- Develop guidelines for how to ensure food safety in collaboration with redistribution actors and donors.

- Provide steady funding for redistribution and food-serving actors in light if their environmental and social services.

It is further recommended, that this project be extended with a phase III, with the aim of implementing the recommendations above in collaboration with actors involved in redistribution in the four countries. This will add additional valuable insights into the further enhancement of food redistribution in the Nordic countries. 



\section{Introduction}

\subsection{Background}

This report summarizes results from phase II in the Nordic project on food redistribution through food banks and direct redistribution (referred to as the Nordic food redistribution project). The project is initiated by the Nordic Council of Ministers through the Green Growth program and financed by the Food and Agriculture program. The Green Growth program aims at greening the Nordic economies through eight prioritized areas, one of which is to develop techniques and methods for waste treatment. Viewing food redistribution as a method for reducing food waste, the food redistribution project falls within the scope of this prioritized area.

Where phase I of the food redistribution project aimed at gaining a first view into the food redistribution activities and potentials in the Nordic countries, ${ }^{1}$ phase II aims at addressing some of the practical issues raised during phase I. The continuation of the project via a phase II was decided in October 2014 by the steering committee on the Nordic Food Waste project, based on preliminary results from phase I. In phase I, the work was largely conducted by national representatives from food safety authorities and national research institutes. In phase II, food redistribution actors have also been directly involved in identifying necessary steps towards enhanced food redistribution in the Nordic countries.

Reducing food waste has been shown to enhance food security and reduce greenhouse gas emissions, especially in the developing countries (Munesue et al. 2015), and redistribution of food through food banks is highlighted by the United Nations Food and Agricultural Organisation (FAO) as a significant mitigation measure in this regard (FAO 2014). Thus, with resources diminishing and socioeconomic disparity growing globally, food redistribution makes a good case for sustainable development due to its ability to serve a two-fold purpose: reducing the environmental impact of food production and supplying those in need with nutritious food. This perspective is relatively novel since food redistribution tradi- 
tionally has been motivated solely by its ability to alleviate immediate social needs among socially disadvantaged people. In the wake of the global financial crisis, the number of people in poverty has risen significantly. In the EU, the number of people in risk of poverty and social exclusion rose from 6 million in 2009 to 120 million people in 2011 (László 2013). The number of people depending on food aid and relying on food banks has risen accordingly. In 2014, almost 6 million people received food from FEBA (European Federation of Food Banks) member food banks (FEBA 2015).

This report comes after a time with heightened media coverage and increased focus on food waste and the possibilities for enhanced redistribution of food at the national, Nordic and European levels. This is connected to an increased awareness of the importance of general waste reduction, and food waste reduction in particular, in the perspective of a circular economy (European Parliament 2015). On 2nd December 2015, the EU adopted an ambitious new Circular Economy Package to stimulate Europe's transition towards a circular economy. The package includes committing to the Sustainable Development Goal of a 50\% reduction in food waste by 2030 (European Commission 2015a). Food waste reduction has thus become a priority among national governments and international organisations alike. In countries where food waste reduction has been on the agenda for more than a decade, significant improvements are starting to show, especially on the amount of food wasted at the consumer level. In the UK, for instance, where the Waste and Resources Action Program (WRAP) has initiated several national initiatives (such as the Love Food Hate Waste campaign), household food waste has been reduced by $21 \%$ from 2007 to 2012 (WRAP 2013).

Improvements are also emerging in the Nordic countries followed by the increased attention on food waste prevention in the industry, at the government level and among the public. In Norway, the gradual change from "use by" to "best by" as an indication of expiration has helped reduce the amount of "expired" food wasted by consumers from 34\% in 2010 to 23\% in 2014 (Hanssen 2015). In Denmark, annual household food waste is estimated to have been reduced from $65 \mathrm{~kg}$ in 2006 to 47 kg in 2014 (Landbrug \& Fødevarer 2015). ${ }^{2}$

All the Nordic countries have developed food waste reduction strategies and some strategic initiatives are aiming at bridging the gap between the actors in the food supply chain. Earlier this year, an agreement was

${ }^{2}$ These numbers are estimates and have not been confirmed by the Danish authorities. 
signed between the Norwegian government and the Norwegian food industry concerning collaboration on food waste reduction initiatives. The agreement involves five governmental departments and ten business organisations and is one of the only agreements of its kind in Europe (Hanssen 2015).

The food redistribution project aims at supporting this positive trend by investigating the potential for food redistribution as an effective method to enhance food waste reduction in the Nordic countries. This report investigates possible solutions to organisational and structural issues dealt with by food redistribution actors and presents "best practices" that are likely to enhance the food redistribution process.

It should be noted, however, that preventing food waste at the source is the main priority of the Nordic governments, in line with the EU waste hierarchy. In this perspective, food redistribution is seen as a potential method for ensuring efficient use of those resources that have already been labeled as waste. Food redistribution is thereby not a goal in itself but rather a means to reach a waste-free society.

\subsection{Main findings from phase I}

Phase I of the food redistribution project aimed at giving a first impression of the current level of food redistribution in the Nordic countries, identifying possibilities for further enhancing such activities as well as pin pointing important areas for further research. Project activities were divided into three main areas relating to the legislative framework pertaining to food redistribution and food banks, the organisation and history of the different national and regional food banks, and the nature and organisation of direct redistribution in the different Nordic countries. The legislative framework was investigated in collaboration with representatives from the national food safety authorities. Information regarding the food banks was gathered in collaboration with the food banks themselves via official and internal documents as well as informal conversations. Direct redistribution was investigated through a survey, which was conducted in two to four regions/cities in each country. ${ }^{3}$

The findings from phase I can be summarised in the following four main points (Hanssen et al. 2015):

\footnotetext{
${ }^{3}$ Regions and cities were chosen to gain an impression of the varying degree of direct redistribution, thus the regions and cities do not necessarily reflect the average level of redistribution and should not be considered representative for the country as a whole.
} 
- Food is being redistributed at a high rate in the Nordic countries, both by national food banks as well as local charity organisations, the former redistributing more than 900 tonnes of food in $2013^{4}$ and the latter serving 1.64 million meals the same year. ${ }^{56}$ However, an even larger amount of food is still being wasted and the potential for redistribution is far from being met.

- The national legislative frameworks that apply to food redistribution and food banks vary between the Nordic countries, although all fall within the food safety regulations of the European Union. Some interpretations of specific regulations are more conducive to enhanced redistribution, with the Finnish Evira Guidelines as an example of instructions aimed specifically at enabling such activities.

- Whereas the structure and function of the national and regional food banks vary between the four Nordic countries, they all share the function as redistribution centres that connect the food sector to the charity organisations or directly to the social clients, as is the case in Finland. Food banks therefore have the possibility to act as "systems operators" in the further enhancement of redistribution systems at the national and Nordic levels.

- The main barriers for increased redistribution identified by food banks and charity organisations alike are lack of efficient organising and systems for quality assurance, sufficient infrastructure, supportive legislative frameworks as well as appropriate financing.

The report from phase I also identifies three areas for further study:

- Comprehensive quantification of food redistribution in the Nordic region, both via national and regional food banks as well as direct redistribution at the local level, in order to gain representative data for all four countries.

${ }^{4}$ This includes the three main food banks in Denmark, Norway and Sweden. No food bank existed in Finland at the time of reporting.

${ }^{5}$ The survey did not include all charity organisations serving meals from surplus food but was limited to actors residing in the two to four regions/cities in each country that were part of the survey. Thus, this amount is assumed much higher when considering all local food redistribution occurring in the Nordic countries.

${ }^{6}$ Since charities mainly register food in meals rather than weight, no total weight was calculated. 
- Development of food banks as "systems operators" in food redistribution through regional networks and collaboration with direct redistribution systems at the local level.

- Development of rules and control routines for redistribution via food banks and especially directly to charity organisations.

Phase II has focused on the latter two areas, whereas the first area has been omitted due to time and funding restraints. The concrete areas of investigation will be described in detail in chapter 2 .

\subsection{Relevant studies}

Since the conclusion of phase I, a handful of studies have been published that address food waste at the Nordic and European levels. Most such studies have researched amounts and causes of food waste as well as possible reduction measures. Where some have focused on single entities, such as households (Aschemann-Witzel et al. 2015; Graham-Rowe et al. 2015; Parizeau et al. 2015) or specific actors in the food industry (Betz et al. 2015, Silvennoinen et al. 2015), others have conducted national overviews of food waste occurrence throughout the food supply chain (Halloran et al. 2014, Katajajuuri et al. 2014). Using life-cycle analysis, one study further highlights food waste prevention as significantly superior to incineration and anaerobic digestion in a global warming perspective (Schott \& Andersson 2015). In fact, earlier studies have found that food waste prevention is eight times more effective in reducing the amount of greenhouse gas emissions compared to anaerobic digestion (Quested et al. 2011). Such research is instrumental in creating a context in which solutions for the causes and effects of food waste can develop.

Some work has also been done on the subject of redistribution and its potential for food waste reduction. In their editorial entitled "The food waste challenge can be solved", the founding members of the International Waste Working Group's Task Group on the Prevention of Food Waste specifically identify redistribution of food as one of the optimal solutions to food waste, next to preventing the occurrence of food waste all together (Williams et al. 2015). A comparative study on EU Member States' legislation and practices on food donation has found that the interpretation of food safety laws varies greatly between Member States and that food redistribution can increase significantly through softer interpretations of the legal framework as well as financial incentives for donation 
(O'Connor et al. 2014). Other studies similarly highlight the potential for redistribution, pointing to the importance of distinguishing between surplus food and food waste in relation to management schemes (Papargyropoulou et al. 2014).

Two recent studies have been conducted in the Nordic context. One has focused on the impact of direct food redistribution on food waste reduction in Norway, investigating both organisational elements and amounts of food redistributed in organisations located in ten Norwegian cities (not including Oslo) (Capodistrias 2015). The study found that 3,500 meals made from surplus food are served daily by charity organisations in these ten cities and that the organisations are characterised by both complexity and efficiency. A main barrier identified in the study is the lack of transportation and storage facilities, which limits the capacity for receiving and serving food. This barrier, the study argues, can be overcome through increased collaboration between organisations (e.g. shared storage facilities among otherwise diverse organisations). The study concludes that the redistribution occurring in the ten cities contribute significantly to food waste reduction and that "surplus food redistribution should be considered as a strategy to reduce food waste" (Capodistrias $2015,25)$.

The other study has a broad perspective on actors, challenges and possible improvements of redistribution from retail stores in Sweden (Pettersson 2015). Part of the study is a survey among ICA retail stores, which gives insight to the opinions and operations of donors. Results show that $30 \%$ of the stores are involved in redistribution today and that roughly $4 \%$ of their overall food waste is prevented in this way. Another conclusion is that redistribution is close to cost neutral for the donor. 


\section{Goal and scope of the project}

\subsection{Goal of phase II}

The main goal of phase II of the food redistribution project is to develop a common platform for how redistribution of food can be further developed in the Nordic countries to prevent food waste without compromising food safety requirements. The platform considers both direct redistribution, often at a local level, and redistribution via food banks, including how the two systems most efficiently can be integrated and complement each other without competing for the same resources.

\subsection{Models for redistribution}

The models and solutions presented in this report should be seen as "best practises" based on experiences from the four Nordic countries as well as international experiences. The report is thus not intended to be a check list for food banks and charity organisations in the Nordic countries, but rather to inspire and allow each organisation and each country to use the elements of the concept that are most relevant for their specific national, regional and local context.

\subsection{Four issues}

Based on the findings and identification of relevant areas for further study presented in phase I, phase II of the food redistribution project has focused on the following four issues:

- Evaluating the EU and national regulatory frameworks for direct food redistribution combined with central redistribution and describing how the regulatory systems function in each country as well as giving input to "good practise models". 
- Developing a framework for how local and centralized food redistribution can be organised where food banks can take the role as food redistribution centres.

- Developing platforms for quality improvement and assurance systems for food redistribution in the Nordic countries.

- Developing systems for registration and tracing of food. 


\section{Methods and data gathering}

The timeframe for phase II of the food redistribution project has been 12 months, from the first project meeting in January 2015 to finalizing the phase II report in December 2015. A survey with follow-up interviews and workshops were the three main methods used for data gathering.

Four Nordic research institutions have been responsible for each of the four issues investigated in the study:

- Østfoldforskning, Norway (Irmelin Gram-Hanssen and Ole Jørgen Hanssen) has been responsible for evaluating the EU and national regulatory frameworks (chapter 5).

- IVL, Sweden (Johan Hultén and Åsa Stenmarck) has been responsible for developing a framework for organisation (chapter 6).

- Luke, Finland (Kirsi Silvennoinen) has been responsible for developing a platform for quality assurance (chapter 7).

- PlanMiljø, Denmark (Mads Werge and Ane Kirstine Aare) has been responsible for developing systems for registration and tracing (chapter 8).

Representatives from national/regional food banks as well as national food safety authorities have provided "best practice" examples and performed quality assurance of the report throughout the project period.7 The research institutions are responsible for the final recommendations.

\subsection{Survey}

A survey was conducted among actors engaged in food redistribution in the four Nordic countries. The actors were identified based on knowledge and contacts gained during phase I of the food redistribution project. Twenty-nine actors took part in the survey, including nine national, regional and local food banks, two logistical centres and 17 actors engaged

${ }^{7}$ For a list of contributing organisations and individuals, see appendix I. 
in serving food to social clients. It is important to mention that respondents do not necessarily represent national activity levels and that not all central players in food redistribution were able to take part in the survey. ${ }^{8}$ Thus, the survey data should not be seen as representative for the four Nordic countries but rather inform the further analysis concerning solutions to the identified issues.

Questions in the survey were developed based on findings from phase I and structured to address the research questions of phase II, thus pertaining to issues of legislation and regulations, organisation, quality assurance and registration and tracing of food. ${ }^{9}$

Analysing the data, actors were divided into two main groups, separating the redistribution actors (food banks and logistical centres) from the food-serving actors as these two groups are operating at different levels in the food redistribution chain. Information was extracted based on relevance for the four issues addressed in the report. ${ }^{10}$

The issues pertaining to the legislative framework for food safety were addressed in collaboration with representatives from the food safety authorities in the four countries in order to ensure relevance and investigate varying interpretations among the Nordic countries.

\subsection{Workshops}

In order to involve stakeholders in the food redistribution chain and get their input on the project, two workshops were carried out during the project period, one in April 2015 and one in November 2015. The first workshop, which was held in Oslo in combination with the FUSIONS project, aimed at engaging participants in dialogue based on the findings from phase I and identifying barriers and possibilities for enhanced redistribution within the various parts of the food redistribution chain. A workshop report was drafted to summarize key points.

The second workshop was held in Gothenburg at the end of the phase II project period. The workshop aimed at engaging participants at a strategic level while gaining input to the concrete recommendations provided in the report. Participants included food redistribution actors, food-serving actors, retail/wholesale actors, industry organisations as well as local

\footnotetext{
${ }^{8}$ For a list of survey respondents, see appendix I.

${ }_{9}^{9}$ See appendix II for a list of survey questions.

10 The actors were able to self-identify as one of the four categories, allowing more nuance in their responses. For the purpose of this report, however, the first three categories are collectively referred to as redistribution actors.
} 
and national food and environmental authorities. Input from participants has been considered throughout the report and especially in chapter 9 on recommendations.

\subsection{Information extraction}

This report is comprised of information gathered through the survey, the two workshops and the findings from phase I as well as other relevant recent research as described in the previous sections.

\subsection{Definitions}

Many different kinds of actors engage in redistribution activities. Several definitions often exist for the same type of actor, which makes it challenging to gain an overview of the potential for collaboration as well as the individual legal responsibilities. Gaining a common understanding of actor definitions would therefore be beneficial. In this report, the following definitions are used:

- A "food donor" is an actor in the food supply chain that donates surplus food for redistribution. Food donors can include primary producers, food industry actors, retailers, wholesalers and the hospitality sector. The food donor can participate in the redistribution process in varying degrees, e.g. leaving food outside the shop door or delivering it directly to redistribution actors/foodserving actors. They may have financial responsibility by paying for logistical services.

- "Surplus food" is food that food business operators are no longer able to or interested in selling, e.g. due to packaging issues, lack of storage space or approaching expiration dates. Surplus food is not yet food waste and can therefore be donated if done in compliance with food safety regulation.

- A "sponsor" is a business, organisation, authority or individual that helps fund redistribution actors or food-serving actors, normally by financial resources.

- A "redistribution actor" is an actor engaged in redistributing food from donors to a central warehouse or directly to food-serving actors. The most common redistribution actors referred to in this 
report are food banks. Other redistribution actors can include logistical centres or redistribution terminals.

- A "food bank" is an organisation that facilitates redistribution for several food-serving actors by running logistics and often storing large quantities of food at a centralised warehouse. The scale of operations is often regional and involves many food donors. Food banks do not serve food but act as redistribution operators.

- A "food-serving actor" is an organisation that serves food or hands out food bags, most often to social clients. They may acquire the food from food banks or by direct redistribution that they run themselves. Most food-serving actors included in this report are charity organisations.

- A "charity organisation" is a non-profit organisation that provides services for social clients, often involving food free of charge or at reduced price. Although charity organisations can also be a redistribution actor, focus in the report is on charities that serve food to social clients.

- An "end-user" or "final consumer" is the person consuming the surplus food, most often through charity organisations. In Norway, however, Matsentralen and food-serving actors are also considered as end-users.

- A "systems operator" is an organisation facilitating redistribution by developing guidelines and donor agreements and monitoring redistributing actors. They can also coordinate logistics for foodserving actors. A systems operator can operate at regional or national levels. At a national level this can be done by a national food bank, a cooperative body of food-serving actors, a national organisation of food industry or retail companies or a cooperative body of all these. 


\section{Survey results}

The survey was conducted among actors engaged in food redistribution, defined as either redistribution actors (food banks and logistical centres) or food-serving actors (mainly charity organisations) in all four Nordic countries. All participating food-serving actors use surplus food and several run their own food redistribution. Among 29 respondents, 11 identified as redistribution actors and 18 identified as food-serving actors. The questions in the survey relate to the four research areas of phase II: legislation and regulations, organisation, quality assurance and registration and tracing of food. In the following sections, the data is presented according to these four themes. In subsequent chapters, the findings are used as a foundation for proposing "best practice" models and recommendations.

Table 1: Type and nationality of respondents

\begin{tabular}{lrrr|rr} 
Country & $\begin{array}{r}\text { National food bank } \\
\text { - open redistribu- } \\
\text { tion to several or- } \\
\text { ganisations }\end{array}$ & $\begin{array}{r}\text { Regional/local food } \\
\text { bank-open redis- } \\
\text { tribution to several } \\
\text { organisations }\end{array}$ & $\begin{array}{r}\text { Internal logistic } \\
\text { centre for redistri- } \\
\text { bution of surplus } \\
\text { food in own charity } \\
\text { organisation }\end{array}$ & $\begin{array}{r}\text { Serving food to so- } \\
\text { cial clients/ } \\
\text { delivering food } \\
\text { bags based on do- } \\
\text { nated food }\end{array}$ \\
$\begin{array}{l}\text { Denmark } \\
\text { Finland }\end{array}$ & 2 & 1 & 0 & 9 & 12 \\
Norway & 0 & 3 & 0 & 3 & 6 \\
Sweden & 0 & 0 & 1 & 5 & 6 \\
Total & 0 & 3 & 2 & 1 & 5 \\
\hline
\end{tabular}

\subsection{Food legislation and regulations}

The majority of redistribution actors and food-serving actors experience regular controls by food safety authorities, $55 \%$ and $64 \%$ respectively. A similar percentage of actors have been certified or approved by the authorities.

More than half of both redistribution actors (73\%) and food-serving actors (64\%) feel well informed about food redistribution regulations by food safety authorities. However, this still leaves nearly a third of actors uncertain of rules and regulations pertaining to their operations.

Generally, respondents do not experience regulations and control regimes as a limiting factor in their food redistribution work. Only $9 \%$ of the 
redistribution actors feel that regulations are too strict. A slightly higher percentage of food-serving actors identify too strict regulations or lack of clear regulations as areas of concern (15\%). The following two figures show the average degree of concern regarding regulations among distribution and food-serving actors respectively.

Figure 1: Degree of concern about strict regulations, too strong regulatory regimes or lack of clear regulations (average), redistribution actors

$$
\text { - Concerned - Not concerned } \quad \text { Uncertain }
$$

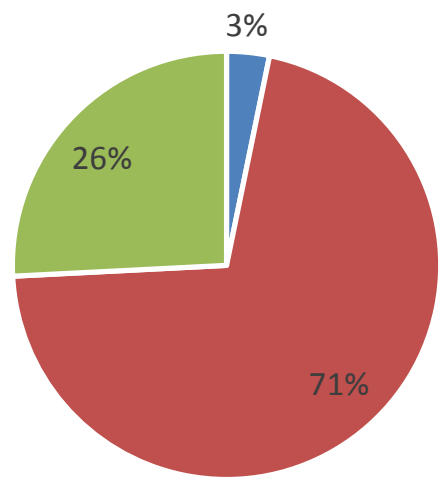

Figure 2: Degree of concern about strict regulations, too strong regulatory regimes or lack of clear regulations (average), food-serving actors

$$
\text { - Concerned } \quad \text { Not concerned } \quad \text { Uncertain }
$$

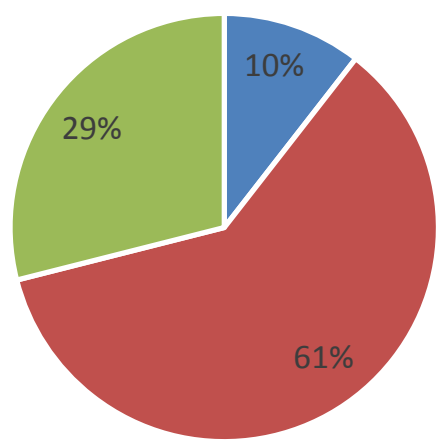




\subsection{Organisation}

\section{Collaboration}

A high percentage of both redistribution actors and food-serving actors have agreements with food donors at the regional or local level, $85 \%$ and $72 \%$ respectively. Similarly, $75 \%$ of the redistribution actors have "many" or "quite a few" agreements with food-serving actors about regular donations. Structured collaboration with other redistribution actors appears more sporadic with 50\% engaging in "some collaboration" with actors at the national level and $43 \%$ collaborating with actors at the regional level. Among food-serving actors, collaboration is noticeably lower with a mere $28 \%$. Competition for food donations is experienced by $30 \%$ of redistribution actors whereas only $17 \%$ of food-serving actors have experienced direct competition with other actors.

\section{Donations}

Retailers are the most common type of donor among both redistribution actors and food-serving actors with $43 \%$ and $37 \%$ receiving food from this type of donor. $22 \%$ and $26 \%$ of redistribution actors receive food from food producers and wholesalers, whereas $9 \%$ mention other actors. For food-serving actors, food banks are the second most common type of donor (18\%), followed by food producers, wholesalers and other actors, such as bakeries and restaurants (all at 15\%). Number of donors does not necessarily reflect the amounts of food received. Therefore, even though redistribution actors have more agreements with retailers than with wholesaler, the latter is likely to provide larger amounts of surplus food, thus being a more important type of donor. This is the case with the national food banks. 
Figure 3: Type of donors, redistribution actors

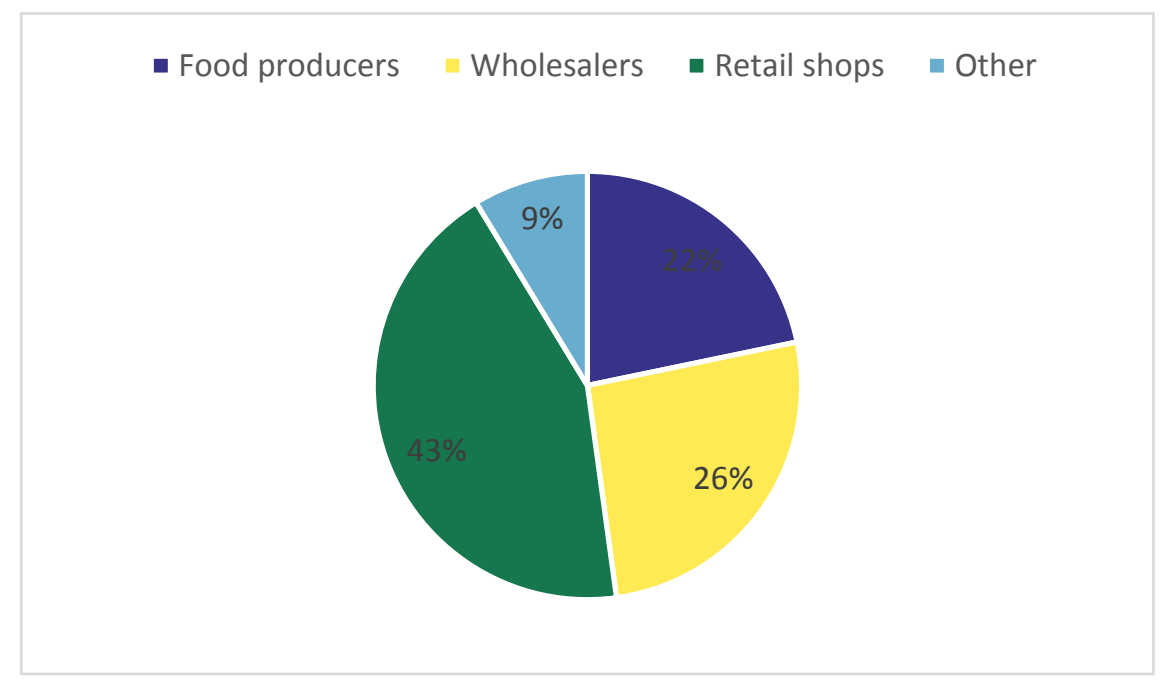

Figure 4: Type of donors, food-serving actors

- Food producers $\square$ Wholesalers $\square$ Retail shops $\backsim$ Other $\square$ Food banks

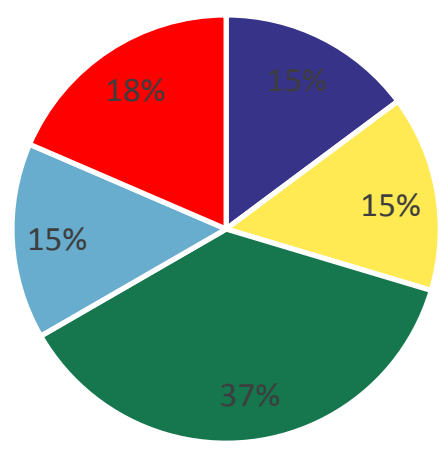




\section{Financing}

Public funding and donations are the most common sources of financing for both redistribution actors (26\%) and food-serving actors (41\%). Public funding is however not mentioned by the Swedish food-serving actors. Service fees payed by clients are more common for redistribution actors than for food-serving actors, with $18 \%$ and $9 \%$ respectively. This type of income is only mentioned by the Danish and Swedish redistribution actors and only by Danish food-serving actors. "Other" funding sources are mainly funding from other parts of the organisation, such as second hand shops or the central organisation.

Figure 5: Funding sources, redistribution actors

- Public funding

Donations

- Service fees from clients $\quad$ Other

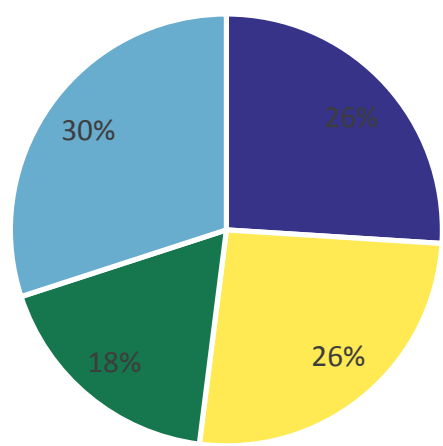

Figure 6: Funding sources, food-serving actors

- Public funding Donations - Service fees from clients $\square$ Other

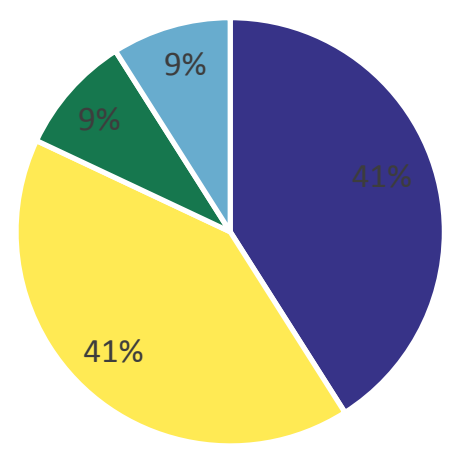




\subsection{Quality assurance}

Whereas the majority of the redistribution actors are approved or are in the process of becoming approved as food business operators by the authorities (64\%), this applies to less than half of the food-serving actors (39\%). The same trend applies to the existence of Quality Assurance (QA) systems in the organisations. Whereas $64 \%$ of redistribution actors have or are in the process of establishing QA systems, this is only the case in $33 \%$ of the food-serving organisations.

\subsection{Registration and tracing of food}

As with quality assurance, systems for registration of food is more prevalent among redistribution actors where $64 \%$ have such systems in place compared to $18 \%$ among the food-serving actors. The majority of the registration systems are electronic (71-67\%). Only 18\% of redistribution actors and none of the food-serving actors have written manuals for how to register food in their organisation.

As becomes clear from the graph below, redistribution actors and food-serving actors prioritize different types of registration. Thus, among the redistribution actors that register food coming in and out of the organisation, type, amount and donor is of main priority. In comparison, the food-serving actors that register food received and served prioritize registering numbers of meals and clients served as well as food bags given out. These three areas of registration are of course also areas that require either direct contact with the end-consumers or calculations that can translate amounts of food into meals and food bags. 
Figure 7: Type of registration in percentage for redistribution actors and food-serving actors

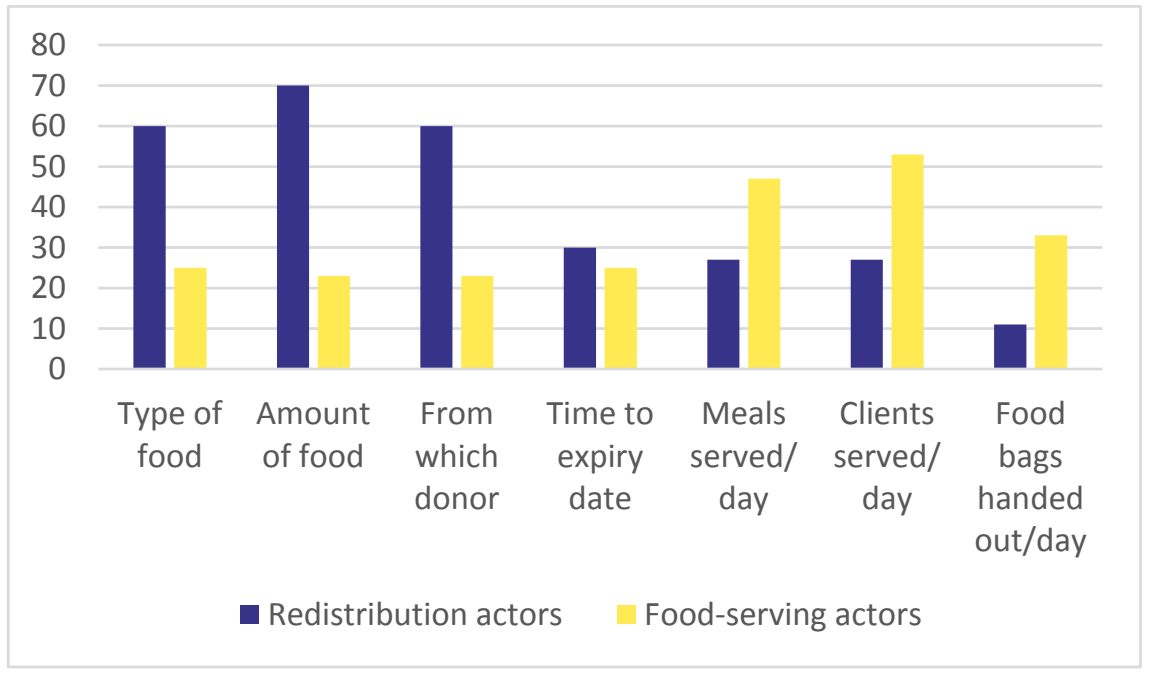





\section{Legislation and regulations: Existing laws and "best practice" guidelines and interpretations}

\subsection{Laws and interpretations}

During phase I, the main legislation and regulations guiding redistribution of food in the Nordic countries were identified. EU food safety regulations are considered the central legal framework for food redistribution activities. However, interpretation of these regulations as well as additional national legislation result in slightly different practices between the Nordic countries.

\subsubsection{Harmonized EU legal framework}

In 2002, the EU obtained a harmonized food law with the passing of Regulation (EC) No. 178/2002, laying down the general principles and requirements of food law, establishing the European Food Safety Authority and laying down procedures in matters of food safety. In 2004, four additional regulations were passed pertaining to the general hygiene of foodstuffs (Regulation (EC) No. 852/2004), additional hygiene rules for food of animal origin (Regulation (EC) No. 853/2004), controls ensuring compliance with feed and food law as well as animal health and welfare rules (Regulation (EC) No. 882/2004), and controls of establishments producing products of animal origin intended for human consumption (Regulation (EC) No. 854/2004). The regulations apply to all food business operators, meaning "any undertaking, whether for profit or not and whether public or private, carrying out any activities related to any stage of production, processing and distribution of food" (European Parliament 2002). In this context, redistribution of food is considered as a distribution activity, and the EU food safety regulations thus apply to all actors engaged in food redistribution, both directly and indirectly. See the report from phase I (Hanssen et al. 2015) or O'Connor et al. (2014) for a detailed 
overview of the four EU regulations and their implications for food redistribution.

The interpretations of rules vary when it comes to occasional food redistribution activities, e.g. among local charity organisations that do not necessarily serve food as an integrated part of their business model. The EU Regulation (EC) No. 852/2004 on the hygiene of food-stuffs states that "community rules should [...] apply only to undertakings, the concept of which implies a certain continuity of activities and a certain degree of organisation" (European Parliament 2004a). Thus, although EU regulations guide every aspect of food safety in a redistribution perspective, most regulations allow for significant interpretation. This was in fact one of the main findings in a comparative study on food redistribution practices among 12 EU Member States done in 2014. Of the four Nordic countries, Denmark and Sweden were included in the EU study, and it was found that these countries generally interpreted EU regulations more stringent than most other countries, such as France, Belgium and Greece (O'Connor et al. 2014). This tendency, as well as the implications for food redistribution, will be further discussed in the sections below.

\subsubsection{National regulations and interpretation of the $E U$ framework}

In all four Nordic countries, actors that engage in redistributing and serving food are considered as food business operators. However, in Norway, the national food bank and the national charities that serve food to social clients are additionally considered as end-users. Being an end-user means that the redistribution of food from producers and retailers to the food bank and charity organisations is similar to the distribution to regular consumers. The process is thereby characterized by less stringent legal requirements and control than redistribution between two regular food business operators.

An area where the four countries vary considerably is in relation to traceability regimes. According to Regulation (EC) No 178/2002 Article 18 , all food business operators are subject to requirements of traceability when delivering food to another food business operator. In Denmark, Finland and Sweden, this includes redistribution to food banks and charities. In Demark, the requirement of traceability means that food business operators need to keep a level of detail in their registration that will allow them to trace food products if a withdrawal is necessary. In Finland, food safety authorities do not require the same level of detail in registration 
and mainly require that donors register to whom they donate. In Finland, there have until recently not been any centralized food banks and food redistribution mainly happens at a local level. This means that donated food reaches the end-consumer shortly after it leaves the donors' premises and avoids longer periods of storage. The local authorities control the Finnish food redistribution/food-serving actors when authorities suspect that the systems used are not sufficient. Control is done in this manner to reduce the administrative burden on donors and redistributors.

\subsection{Legal challenges and possible solutions}

As part of phase I, participating food banks, food donors and charity organisations identified experienced and perceived legal barriers to food redistribution. The barriers are summarized as interpretations of regulation, reporting requirements and fees, Value Added Tax and lack of political prioritization. Similar barriers were identified in the recent comparative study among 12 EU Member States done by O'Connor et al. (2014).

\subsubsection{Interpretations of legislation}

As shown in the survey results (chapter 4.1), the majority of redistribution actors (73\%) and food-serving actors (64\%) who participated in the survey feel competent in understanding and complying with the food safety regulations that pertain to their type of activity. This means, however, that nearly one third of these actors feel uncertain or uninformed about certain parts of their legal obligations. Similarly, in interviews and informal conversations with potential food donors (mainly wholesalers and retailers) during phase I, uncertainties about legal obligations were identified as a main hindrance to donating surplus food. This was also found in a Swedish study from 2015 (Pettersson 2015), and further correlates with the 2014 study on redistribution practices among EU Member States, which highlights the fear of risks associated with liability for donated food both from a financial and reputation perspective ( $O$ 'Connor et al. 2014).

Potentially due to the relatively recent history of food redistribution in the Nordic countries, no country except Finland has clear guidelines specifically pertaining to food redistribution activities. As seen in the beginning of this chapter, accessing EU legislation requires some experience understanding and interpreting the legal definitions. On top of this comes national interpretations and additional national legislation. As 
also shown above, certain definitions leave considerable room for interpretations, e.g. "a certain continuity of activities and a certain degree of organisation" pertaining to food of animal origin. For some potential donors, this is enough of a barrier to prevent them from engaging in food donation. How a food business operator fits within the national legal framework depends on a variety of factors, including how much and what kind of food is redistributed as well as to whom the business is redistributing food. Therefore, a continuous dialogue with the appropriate authorities is necessary. National guidelines for how to interpret such legislation can also be a helpful tool for food business operators and can potentially enhance food redistribution activities. This is discussed further later in this chapter.

\subsubsection{Control requirements and fees}

Besides complying with food safety requirements, living up to control requirements and paying for control fees is another barrier for actors engaged in food redistribution. The control requirements and the connected fees vary between the four Nordic countries. In Norway, controls of food business operators dealing with redistribution are free of charge. In Denmark, controls of retailers are free of charge, although the actor will be charged with fees for a subsequent control if the ordinary control was not satisfactory. In Finland, food banks and charity organisations are charged with a control fee like other food business operators, but such actors are first controlled if local authorities have reasonable doubt about their compliance with food safety requirements.

Some regulations are not burdensome because of their restrictions but simply because of the documentation required at controls. One such regulation is article 1.5.b.ii and $\mathrm{c}$ in regulation 853/004 pertaining to the donation of food of animal origin. Producers and retailers are only allowed to distribute food of animal origin to other retailers if this is held as a marginal, localised and restricted activity and if national legislation has been put in place to regulate this. The interpretation of marginal, localised and restricted varies between countriesIn Denmark, the interpretation of localised can either be $50 \mathrm{~km}$, administrative region or national borders depending on the food product. In Sweden and Finland, localised is interpreted as municipal and regional border respectively. Whereas complying with this rule does not seem to be a problem among most producers and retailers, securing documentation of compliance for controls adds an extra burden to redistribution activities. As described in the previous sub-section, Finland has a different control regime when it comes to 
compliance than e.g. Denmark and Sweden. Thus, reporting requirements are seen as less of a burden in Finland than among actors in the two other countries.

\subsubsection{Value Added Tax (VAT)}

In EU Member States, food business operators are exempt from paying VAT on food, which has been discarded. In some countries, this is not the case when food is donated. This is guided by EU-tax legislation on the common system of value added tax, which states that food donors have to pay VAT "if the donation is made by a taxable person and if the VAT on acquisition of the goods is fully or partially deductible" (European Parliament 2006). Thus, in some cases food business operators have a financial incentive to discard food rather than donate it to food banks or charities (O'Connor et al. 2014). In relation to other food waste reduction initiatives, such as social supermarkets, VAT has also been highlighted as a barrier to the financial feasibility of such activities (Petersen and Koldborg 2014). However, the interpretation of this legislation varies between countries. As a way to circumvent the VAT problem, the European Commission has recommended that food business operators set a value close to zero on foodstuffs that are close to their "best before" date, or that cannot be sold due to their external appearance, since this will simultaneously reduce the VAT. The Commission further underlines, that "it is up to the Member States to apply this principle with flexibility so as not to impede taxable persons from donating foodstuff to charities" (European Parliament 2013).

The issue of VAT is also a central theme in the comparative study by O'Connor et al. (2014). According to the authors, the majority of stakeholders in the study identified food donor liability for the VAT on donated items as a hurdle. The study found that a stringent interpretation of the VAT Directive, such as in Sweden and until recently in Denmark, actively impedes the redistribution of surplus food between industry and food banks. One of the main uncertainties concern whether food nearing its "best before/use by" date retains its original commercial value or can be given a zero value (O'Connor et al. 2014). The issue of VAT is currently being debated in the EU and during the development of this report the "close to zero" approach was adopted in Denmark as well (SKAT 2015). 


\subsubsection{Lack of political prioritization}

During phase I, both food banks and potential donors in some of the Nordic countries noted that a stronger political prioritization at the national, Nordic and EU level could greatly enhance food redistribution. Such prioritization could be expressed through financial incentives in terms of either added costs connected to the discarding of surplus food, or financial gains (e.g. tax deduction) connected to the donation of surplus food. The comparative study of EU Member States also found a strong connection between fiscal incentives for food donation and high amounts of food donated to food banks and charities. Only three of the Member States in the study had such incentives in place: a $60 \%$ and $35 \%$ tax credit from income corporate tax in France and Spain respectively. In Portugal, donors can deduct $140 \%$ of the food at the time of donation as long as the food is donated to social purposes and limited to $8 / 1,000$ of the donor's turnover (O'Connor et al. 2014).

Another barrier identified in the EU study, and related to the issue of VAT, is the lack of specific prioritization of human food over energy recovery in the waste hierarchy. Whereas the Waste Framework Directive (Directive 2008/98/EC) identifies a certain order in waste management (prevention, preparing for re-use, recycling, recovery and disposal), the Directive does not consider food waste specifically. Thus, the Directive does not clearly state which prevention or re-use strategy national governments should prioritize. This is especially problematic in the perspective of high national investments in biogas infrastructure as well as financial incentives such as investment subsidies in both Denmark and Sweden. These investments may not make waste management cheaper for the potential donor, but can be seen as political support for treatment further down the waste hierarchy. In the UK and Belgium, the following order of preference has been proposed: prevention, redistribution to humans, feeding to animals, energy or nutrient recovery by methods such as Anaerobic Digestion (AD), composting, and landfilling (O'Connor et al. 2014).

\subsection{Food safety guidelines}

As described above, food redistribution falls within the scope of regular food business operation and therefore regular EU food safety regulations apply to such redistribution activities and actors. Still, the regulations are flexible and through certain interpretations of the EU regulations and 
through national legislation it is possible to help facilitate food redistribution while still ensuring compliance with the EU food safety regulations. This is the case with the Finnish Evira Guidelines for foodstuffs donated to food aid, described below.

\subsubsection{Evira Guidelines}

In the Evira Guidelines, introduced in 2013, the Finnish Food Safety Authority addresses several key barriers for food redistribution. The goal of the guideline is to enable food waste reduction in Finland while ensuring that food redistribution is conducted safely. The guidelines present interpretations of some of the laws concerning the handling and serving of food for organisations or businesses dealing with food aid, which makes redistribution easier and less costly. The guidelines also simply work as a manual for potential donors, food banks and charity organisations in case of dispute or doubt about the general laws pertaining to food safety (Evira 2013). Since the introduction of the guidelines, the Finnish redistribution actors and food-serving actors have seen an increase in donated food. The following paragraphs provide an overview of some of the central points in the guidelines:

Registration: Organisations involved in serving donated food have to register as a food retail facility to the local food control authorities. However, organisations that only serve vegetables and/or dried goods that are stored at room temperature do not have to register. This limits the administrative burden on redistribution actors.

Control: As described above, local authorities conduct regular controls with food business operators at the cost of the food business itself. Although food banks or redistribution organisations fall into the category of food business operators, the Evira Guidelines say that food business operators dealing with food redistribution will be controlled when authorities have reasonable doubt as to the safety of the operation. As with registration requirements, this cuts down on administrative costs for the redistribution actors.

Labelling: Food with wrong labelling can be donated for food redistribution as long as the donor provides correct information regarding the actual content of the food. This information needs to reach the enduser/consumer. This allows for increased redistribution of food that is suitable for eating but would normally be thrown away due to issues not pertaining to the edibility of the food.

Expiration date: Food labelled with "use by" can be donated after the expiration date as long as the food has been frozen before this date. The 
donor is responsible to note the freezing date and to deliver the food to the end-user no later than two months after this date without disrupting the cool chain. If such food items are delivered to the consumer partly or completely thawed, information should be given instructing consumers not to refreeze the food and to consume it as soon as possible. Food labelled with "best before" can be donated as food aid after expiration based on a visual inspection of the food. Organisations that cook food and serve it to clients can use donated food up until one day past the "use by" date as long as the food passes a visual inspection and is cooked at a minimum of 70 degrees Celsius. In Finland, many food products are labelled with "use by", even though the majority of these products would be eligible for a "best before" label. Instead of wasting edible food products that are passed their "use by" date, the Evira Guidelines thus enables a case-tocase based evaluation of these food products.

Cooked food: Food that is cooked and served hot or cold (e.g. at a restaurant or cantina) can be donated for food redistribution as long as this is done within four hours of cooking and as long as the heat (60 degrees Celsius) or cool ( 6 degrees Celsius) chain has not been broken. This helps increase donations from restaurants that generally constitute a segment in the food supply chain with a high amount of food waste and a relatively low donation rate.

Cold and heat chains: Whereas hot food needs to stay at a temperature of 60 degrees Celsius during transportation, the cool chain is allowed broken momentarily as long as it does not cause health risks for the end-users. In addition, if refrigerated vehicles are not available, coolers can be deployed during transport, and if no refrigeration is possible whatsoever, the transportation should be done in a timely manner to avoid significant change in temperature of the food items. Many redistribution actors mention the lack of refrigerated vehicles as a significant barrier to receiving and transporting frozen foods. This point thus allows actors to make decisions on a situation-to-situation basis on when it is safe to transport food in un-refrigerated vehicles, depending on the type of food, the distance and the timeframe for using the food.

\subsubsection{Danish FAQ guideline}

The Danish Veterinary and Food Administration has launched an initiative aimed at limiting food waste at the retail and hospitality sectors, e.g. through donating surplus food to food banks or directly to charity organisations. The initiative includes a question and answer application available on the administrations' website, where food donors can indicate the 
condition of the surplus food and get an immediate indicator of whether or not the food is safe for donation. Categories include damaged packaging, wrong labelling and leftovers from buffet among others. ${ }^{11}$ The online application does not cover nearly as many aspects of food safety questions as the Finnish Evira Guideline, but it does provide a quick guide to potential donors on a case-to-case basis and as such is a helpful tool for interpreting food safety legislation. Nothing similar exists in Norway or Sweden.

\subsubsection{Industry guidelines}

Several individual businesses that wish to be in the forefront of food waste reduction measures have developed own guidelines for how to secure food safety during redistribution activities. One such business is the Swedish retail chain Axfood, who have worked strategically with sustainability and Corporate Social Responsibility (CSR) the past ten years. Earlier this year they finished an Axfood guideline for how to ensure quality and efficiency in activities related to donation of surplus food. The Axfood guideline is further described in chapters 7 and 8 on quality assurance and registration \& tracing.

\subsection{Extended producer responsibility}

Besides the national differences in concrete regulation, there is also differences in how the four countries view the role of authorities and the obligations of industry. Whereas Finnish authorities have taken it upon themselves to help enhance food redistribution by clarifying, and in some cases changing interpretations of regulations through the Evira Guidelines, Norwegian food safety authorities are more inclined to let the industry take the lead. Earlier in 2015, the Norwegian government signed an agreement of intent with the food industry, which aims at reducing food waste. A plan indicating goals and responsibilities is expected signed by mid-2016 (Regjeringen 2015). Norway has a long tradition of involving industry more actively in processes towards enhanced environmental performance. In the late 1990s, the Norwegian government signed a similar agreement with the business sector agreeing on extending the producer responsibility concerning recycling of packaging materials (glass,

11 http://www.foedevarestyrelsen.dk/Selvbetjening/Guides/Sider/Saadan-kan-virksomheden-undgaa-madspild.aspx 
plastics, metals, paper and cardboard). Rather than applying laws and regulations, the agreement was an attempt to let the industry solve environmental and resource related issues as efficiently as possible. The agreement resulted in the establishment of a producer responsibility organisation (Grønt Punkt Norge), ${ }^{12}$ financed through industry memberships, which now successfully collects all fractions for recycling or energy recovery.

The EU framework supports industry-initiated guidelines through Article 8 in Regulation 852 on the general hygiene of foodstuffs. The article states that when national guides describing good practice are developed, they should be developed and disseminated by the food business sector in consultation with the competent authorities and consumer groups. In both Denmark and Sweden, industry organisations use this ability when developing new procedures and guidelines in order to ensure compliance with current legislation. The authorities do not have to adopt such guidelines at the national level, but they are obliged to look through them and control for compliance. Article 8 in Regulation 852 can prove helpful in the further collaboration between industry and authorities in Norway as well as in the other Nordic countries.

\subsection{Recommendations}

Due to differences in national legislation between the four Nordic countries, developing a harmonized legal framework for food redistribution in the Nordic countries is not feasible or preferable at this point. However, it is within the scope of this project to suggest best practices for legal guidelines and interpretations of the EU legal framework as well as highlight possible benefits and challenges in a potential future harmonization process.

\subsubsection{Create national or sector guidelines}

All four Nordic countries are concerned about reducing food waste and see possibilities in doing so through food redistribution practices. Current initiatives and practices vary depending on both how long such activities have been common in the country and how various actors are seen as responsible for securing effective use of resources.

${ }^{12}$ http://www.grontpunkt.no/ 
One central recommendation concerns the existence of clear guidelines that describe the relevant food safety regulations and how these apply to different actors involved in the redistribution activities. Whether such guidelines are provided by authorities or developed by the industry can depend on national context and preference. Article 8 in Regulation 852 on national guides can prove helpful in this process.

\subsubsection{Remove financial disincentives}

Another recommendation is for national food safety authorities to consider the possibility of reviewing certain existing regulations, or rather interpretations of such regulations. Interpretations found in other EU countries show an inherent flexibility within the EU regulatory framework and can thus inspire the Nordic countries to consider facilitating food redistribution in current and future interpretations. The regulation on VAT falls within this category. Financial disincentives have been highlighted by several producers/retailers as a barrier to donation of surplus food. Thus, a reduction or complete removal of VAT on food donations could be one way to remove this barrier. This could be done, as the EU suggests and as several Member States have already done, by enabling donors to set the value of the food items close to zero before donation.

\subsubsection{Create Nordic standards for future EU guideline}

On 2 December, 2015, the EU adopted an ambitious new Circular Economy Package to stimulate Europe's transition towards a circular economy. The package includes committing to the Sustainable Development Goal of a 50\% reduction in food waste by 2030 (European Commission 2015a). Currently, the Working Group on Food Losses and Food Waste comprising of an Expert Group and member state representatives, is identifying best practices and developing suggestions for possible EU actions to reduce food waste (European Commission 2015b). It is thus likely that an EU Guideline for food redistribution will be developed and launched within the next year.

Whereas it is important to avoid establishing two different guidelines that might confuse rather than aid actors involved in food redistribution, a common ground among the Nordic countries can inform and support the further development of an EU guideline. Some member states are participating actively in the development of these guidelines, and of the Nordic countries Denmark and Norway are part of the mem- 
ber state working group. The food authorities in Denmark have submitted suggestions for changes in current EU legislation that will enable enhanced food redistribution. As with other areas, the Nordic countries have the possibility to present a common standpoint and enable more ambitious strategies and targets to be implemented at the EU level. Being proactive about this work will also ensure that Nordic-specific considerations are taken into account in the formation of a future EU guideline for food redistribution. 


\section{Organisation: Developing sustainable business models for food redistribution}

This chapter identifies organisational barriers for food banks and other redistribution schemes to grow and presents recommendations for improving redistribution quantities and surplus food quality. As food banks today are very different from each other and are all adapted to local circumstances, it has not been possible to develop an "ideal model", but rather a set of guidelines.

\subsection{Different organisational set-ups}

There does not seem to be a common model for how redistribution of food is carried out in the Nordic countries, not even the definition of a food bank is clear to many dealing in redistribution. The variety of business models is large and there are few obvious best-case practices. All organisations have their history explaining why operations are run as they are, a history often heavily influenced by the personal beliefs of founders and managers. What might differentiate Nordic redistribution organisations, especially food banks, from other European food banks is a higher focus on food waste prevention, not just social work. This is probably due to the relatively short history of Nordic food banks and the increased awareness of food waste during the last decade and the relatively well functioning welfare systems in the Nordic countries.

The first report in this project examined the organisation of the three biggest food banks in the Nordic countries:

- fødevareBanken is the oldest, founded in Copenhagen in 2009 as a non-profit. The food bank has approximately 100 recipient organisations, mostly charities, and is funded by public and private donations and membership fees. 
- Matsentralen in Oslo was founded by five large charity organisations in collaboration with companies in the food industry and authorities. They own one truck and rent warehouse facilities from a subcontractor. The warehouse staff is hired by the subcontractor and paid by Matsentralen. All agreements with donors and financiers are done centrally at Matsentralen. In 2015, Matsentralen reorganised as an association due to tax benefits.

- Allwin in Gothenburg is run as a commercial company, charging donors to pick up surplus food. Unlike the previous two food banks that mainly deal with food producers and large amounts, Allwin mainly service retail stores by daily pick-ups and direct redistribution to several food-serving actors instead of using a warehouse.

Finland has been involved in food redistribution activities longer than the other Nordic countries, which among other things is related to a higher population in need of food aid (see Hanssen et al. 2015). The organisational set-up of redistribution activities varies from that of the other countries as well. Until 2014, Finland did not have any official food banks (according to the FEBA definition). However, Finland has been an active member of the Fund for European Aid to the Most Deprived (FEAD), through which food is bought and distributed to the target group. Activities conducted under FEAD shall be coordinated in the field of public health and against food waste.

During 2014-2015, 33 partner-organisations delivered FEAD food to 480 distribution points, many of whom also serve surplus food. FEAD food and the redistributed surplus food is viewed differently, e.g. requirements exist as to the nutritional value of the FEAD food.

For the purpose of the report, two Finnish food banks are considered:

- In 2014, the city of Vantaa started collaborating with several churches on organising a food bank, Yhteinen pöytä, as part of the city's food aid program. It has its own fleet of cars and a warehouse.

- Operaatio Ruokakassi in the Turku area do not consider themselves as a food bank, but rather as a network of food-serving actors. By cooperation, they facilitate efficient logistics and donor agreements. 
There are a few more examples of organisations that operate similar to a food bank or facilitator of direct redistribution. A large proportion of the meals served by food-serving actors made of surplus food are however not from food banks, but from direct redistribution. An estimation of the proportions is difficult to make. A comparison between fødevareBanken, which is the biggest food bank, and the combined efforts of 53 charities in the ten largest cities in Norway, excluding Oslo (Capodistrias 2015), gives some idea of the proportions. fødevareBanken provided approximately $1,007,000$ meals in 2014 served by member organisations. The Norwegian charities provide approximately 1,283,000 meals without the assistance of official food banks. The operational setup and size of these charities varies. Therefore, when considering redistribution, food banks should not be the sole focus.

\subsubsection{FEBA guidelines}

The European federation of food banks, FEBA, has developed guidelines for food bank setup and organisation (FEBA 2007). As it is based on much knowledge and experience, they should be considered when starting and organising redistribution schemes. The guidelines have been important for Matsentralen, but were not used by other Nordic food banks, although fødevareBanken is currently a member of FEBA.

The FEBA definitions of what a food bank is are quite clear, e.g. it should have a warehouse and transport food only to charity organisations. The guidelines are also strict about how the food bank should be organised, with different committees in charge of the different tasks. Most Nordic redistribution schemes are not organised in accordance with these guidelines. Rather than being a template for how food banks should be, the FEBA guidelines can inspire the Nordic food banks in their further development. 


\subsection{Organisational challenges}

Even though the organisational structure and operation differs, the Nordic redistribution organisations share several challenges.

\subsubsection{Finance}

Most organisations struggle to gain enough income to sustain and expand operations. Most organisations receive income from several different sources:

- Public funding and donations are common for food banks and organisations serving social clients. In some cases, the funding is earmarked for individual projects within the organisation and does therefore not provide a reliable income over time. Donations from companies can also be non-monetary, for example a vehicle or consultancy.

- Some organisations receive funding from other parts of their own organisation, such as a second hand shop or a church community. This is common when food redistribution complements other social work.

- Food banks provide logistical services to both donors and foodserving actors. How the food banks finance these services differs. For example, a client can pay according to the amount of food being transported or via a membership fee. fødevareBanken charges its recipients a symbolic fee, which partially covers the cost related to transportation (diesel). fødevareBanken is currently developing a system where donors are charged a service-fee. Allwin charges the donors for the logistical service provided.

- Many of the organisations are also dependent on volunteers as a way to offset logistics and planning costs. Food redistribution, and charity work in general, attracts volunteers for social and environmental reasons.

The organisations that depend much on donations have to spend a lot of time promoting themselves publicly or directly to potential donors. This also makes financing unpredictable since large amounts are sometimes donated from a single donor while other times incomes are low, not correlating with the actual costs at any given time. Another form of income is volunteer work. Here the same problems can occur when recruiting volunteers, who might be more or less committed at different times for their personal reasons. 
As the charities historically have focused on social work, it is not surprising that public funding or donations are natural ways of financing activities. As food waste prevention has risen on the political agenda, it has become more evident that redistribution is a service provided to food retail and industry, lowering their costs of waste management. Instead of paying a waste management company for incineration or anaerobic digestion, they can donate the surplus food, most often free of charge. This elimination of costs is of course an incentive to donate. If donors would pay at least part of the logistics cost, redistribution could be cheaper than waste management and provide some income to the redistributing organisation for the service provided.

In a Swedish study on food redistribution (Pettersson 2015), none of the charities examined charged donors for the logistics service. The study also included a survey of ICA retail stores, which showed that $60 \%$ of the stores spent no extra time on donating food instead of throwing it away. In $23 \%$ of the stores, only 1-15 minutes were spent a day for donating food and $13 \%$ even saved time when they donated food instead of throwing it away. However, because the avoided cost of waste management is low, the calculated maximum profit was only SEK 7,100 annually. From the stores' point of view, the choice of donating food can be seen as near cost neutral.

Committing to redistribution is also a form of Corporate Social Responsibility (CSR), providing goodwill to the company, perhaps more valuable than advertising. According to several retail shops that collaborate with food banks the initiative creates happy employees, as they see the social and environmental benefit of their employer. Bearing this in mind, the redistribution services provided by the food banks and food-serving actors could be perceived as more valuable than a simple reduction in waste handling costs, and thus organisations could charge a higher fee for their services. Especially the larger food banks strive to get more of their funding from industry clients. However, food banks and food-serving actors often find it difficult to charge money for their service, largely because it is viewed as "a good deed".

\subsubsection{Logistics costs}

Costs for vehicles and drivers, storage facilities and sorting are significant. Efficient logistics are difficult to achieve on the relatively small scale of present food banks. In areas with many donors and receivers, there is a high possibility for co-transportation and full usage of vehicles and warehouses capacity. 
When donors are food producers or wholesalers, which is often the case for larger food banks, volumes vary a lot from day to day. This forces the food bank to make single pickups at short notice. Retail shops provide a more even flow of mixed products, but sorting and repackaging at a warehouse is labour intensive. Stockholm City Mission aims to involve persons in job training, doing the sorting from shops. Even though it may not be very efficient from a logistics point of view, offering job training is part of the organisations social work.

One way of lowering the operating costs of food banks could be to transfer transportation activities on to the donor rather than food-serving actors or a food bank. This transfer of costs to the donor would be a break of praxis, but may under specific circumstances enable more efficient logistics as the surplus food can be co-transported with other deliveries. This is a way of donor companies to pay for the CSR-work provided by food-serving actors. According to Capodistrias (2015), there are a few examples of Norwegian donors that transport surplus food directly to charities, which in many cases do not have their own vehicles. The operation in Trondheim, Norway by Bjørn Eklo stands out by having an agreement with the distribution company BRING that lets him use a big storage space and their transport fleet free of charge.

In Stockholm, the City Mission opened a "social supermarket" at the end of 2015, which sells donated surplus food at low prices. Several potential donors were contacted and costs were discussed. Fundraising has been relatively easy, probably as the City Mission is well known. It has been their experience that after an open discussion about the possibilities, most companies find it reasonable to pay a logistics fee.

There are limits to how much transportation can be done by donors:

- Wholesalers often donate large volumes, yet in order to deliver food directly to a large number of food-serving actors, they usually need trucks that are small enough to be able to drive in the city centre. Having more, smaller trucks is an option, but this process is more time consuming due to the number of employees needed. Further, there are limits to how much recipients can receive per delivery. Large volumes of specific food categories can instead be transported by wholesalers to food bank warehouses.

- For donors it is essential that the right recipients receive the donated food and that food safety is ensured throughout the process. Ensuring this is time consuming and it requires continuous work to be up-to-date. If donors do this work, they essentially become food banks, rather than supporting food banks. 


\subsubsection{Professionalism}

Many charities find it difficult to negotiate agreements with food companies and retail chains as these are large and complex whereas most foodserving actors are small. Food companies and retail stores demand reliable and efficient service such as:

- Pickups every day from retail stores, as surplus food arises continuously. Reliability of pickups requires reserves of staff and vehicles.

- Easy system for traceability. The store is required by law to be able to show who has received the food, the same goes for the redistributor (this varies slightly between countries). Possibility to use hand scanners is important.

- Quality assurance to avoid bad publicity caused by the lack of good food hygiene.

- Different industries and stores have different needs. By mapping and understanding these, a better service can be provided.

Larger food banks have better possibilities than small charities to provide these services and to negotiate deals, but continuous improvement is seen as necessary. Without detailed agreements, it may be difficult to ensure that surplus food is safe and nutritious. There are, however, incentives for donors to try to get rid of as much edible food as possible as this usually lowers their waste management costs. These risks are also alleviated by, and thereby dependent on, strong social bonds between the charities and donors (Capodistrias 2015). The Salvation Army in Stockholm emphasizes the importance of continuity in deliveries. For donations to be efficient, they should be part of the day-to-day business of the donor. This way the donor gets a good routine and delivers what the charities want.

Voluntary work is common in all organisations dealing in food redistribution. It is not possible to expect as much from a volunteer as from an employee, even though the volunteer might be equally motivated. Reliability becomes a problem when too much responsibility is assigned to a volunteer. 


\subsubsection{Effectiveness in preventing food waste}

Another obstacle is the quality and expiration date on donated food from shops. Often fruits and vegetables need to be used within one day of donation. It is a challenge for kitchens serving lunch for e.g. 100 persons to use the different fruits and vegetables while they are still fresh. One risk is that the food waste is simply moved from retailers to redistribution actors and food-serving actors.

The varying standards of different food-serving actors are of importance in direct redistribution. There is a difference between food-serving actors that cook and serve food once a week and "professional charities" serving 100-150 meals a day and working with professional cooks that ensure nutritious food and menus that vary from day to day. Furthermore, the big amounts of food that need to be prepared within a tight schedule makes it difficult to use all the donated food while it is still fresh. Other charities, not serving meals every day or providing food bags, may have other possibilities to adapt their planning according to the food they receive. This does not necessarily mean that no food is wasted from the food-serving actors or their clients. These aspects are important for donors to know of and consider in their donation practices.

The risk that surplus food is wasted at the food-serving actors may not be considered when developing agreements with donors. Yet, lack of coordination risks lowers the effectiveness of food waste prevention by transferring parts of the problem. Alexander and Smaje (2008) studied the overall effectiveness in a case of redistribution from two supermarkets to two charities serving meals in Southampton. They concluded that food waste, as well as packaging waste, rose through the redistribution chain. Of the donated food, only $68 \%$ ended up on the plates and the rest (mainly fruit and vegetables) was discarded. The study by Capodistrias (2015) does not measure amounts of food waste, but concludes from many interviews with charities that the food has high quality and very little is wasted.

The food bank of the Salvation Army in Stockholm continuously checks the expiry date of received food and gives feedback to the donors if low-quality products are donated frequently. In some cases, agreements have been cancelled, mainly with smaller stores and delis. Proper discussions and agreements of which food the food-serving actors want should take place before redistribution commences. fødevareBanken follows similar procedures, where the logistics manager is in continuous contact with donors in order to ensure that expectations for food quality are met. Volunteers at fødevareBanken also examine the expiration date and condition of the donated food. The guiding question is "would you eat it yourself?". 


\subsubsection{Communication between organisations}

Much of the redistribution done today is by local charity organisations or local units of larger organisations. These are often operated by socially engaged volunteers and are run independently of each other. Often individuals are driven by wanting to do something in their neighbourhood or religious community. Because of this setup, collaboration between different food-serving actors is often low.

Because of the small scale of most operations, there are some obstacles for increased redistribution:

- Lack of awareness about redistribution among many potential donors. As much is done "under the radar", many do not know about local food-serving actors and they have difficulties promoting themselves. The most common reason for stores not to donate, according to a survey of Swedish ICA-stores, is the lack of known receivers (Pettersson 2015). Although many places lack potential receivers, the study by Capodistrias (2015) shows that redistribution is not only present in the biggest cities, but that medium sized towns often have several charities.

- There might be higher acceptance of donating surplus food if benefits are made visible to the public. Some store managers do not wish to donate publicly and others not at all because of concern of bad publicity (Pettersson 2015). The food-serving actors usually receive positive reactions to the schemes. This implies that more publicity and information may be beneficial for redistributing organisations.

- Common information to potential donors is lacking. Today, there is lack of knowledge within the food and retail sector on possibilities of redistribution, both how it is done and what local organisations exist.

- Companies in the food industry and retail are often large. They have expectations of large-scale operations and efficient logistics.

- Valuable experiences within an organisation are often not shared.

- The food-serving actors lack a common voice in dialogue with donors, authorities and the public. A common platform could prove useful for negotiations and facilitating the needs of redistributing organisations.

A local or regional food bank could work to bring the food-serving actors together. This would facilitate communication and logistics towards the donors. In some cities, however, direct redistribution is extensive and the 
charity organisations may not see the benefits of a food bank conducting more transportation. What is then needed is a common platform for organising the different organisations and work with the obstacles mentioned above.

In Denmark, fødevareBanken acts as a link between the donors and the charities. fødevareBanken also tries to strengthen the link between the charities through annual meetings with the recipient organisations as well as through the closed Facebook group, "MadUniverset", where the cooks at the recipient organisations can share their food experiences.

\subsection{Recommendations}

Based on the challenges presented above, several possible solutions and subsequent recommendations regarding organisation of food banks and direct redistribution schemes can be proposed.

\subsubsection{Develop regional platforms as systems operators}

A great deal of organisations provide valuable social work in their local community, often involving collection of surplus food as a side activity. There is a strong will to keep doing local charity work. Churches and other organisations often work with volunteers at the local level, developing personal relationships with the visitors. Serving of food is often just a means to achieve the goal of social inclusion. Therefore, small-scale operations are necessary. The organisations would however gain much from having a common platform for discussing common issues, at the regional or national level. Important activities include:

- Share experiences.

- Develop common guidelines and agreements with donors.

- Promote redistribution to potential donors and raise awareness of the possibilities of redistribution to minimize waste and provide food to those in need.

- Divide the market of donors and plan the logistics of redistribution.

- Discuss which resources to share, for example vehicles and storage.

- Develop common guidelines and spread information about legislation and proper handling of food.

- Communicate and negotiate with authorities. 
A common platform can be defined as a systems operator. Which specific tasks will be performed by the systems operator will vary depending on the needs of the region. The overall objective should be to facilitate and coordinate redistribution within a geographical area, by performing some or all of the activities listed above. The study of direct redistribution in ten Norwegian cities by Capodistrias (2015) concludes that storage facilities and vehicles are under-utilized by some organisations, while other organisations lack these resources. Increased sharing could thereby increase redistribution with existing resources. A common platform could also facilitate collaboration between redistribution actors and other actors engaged in food aid, such as the FEAD program. In countries where the FEAD program is used actively, like in Finland, new and current redistribution actors could benefit from the availability of this existing logistical infrastructure (European Parliament 2014).

Logistics are often done by different IT-systems, calculating the most efficient routes of transportation. This is also possible in redistribution. There are several European examples of IT-systems developed to link donors to receivers, e.g. Foodcloud in Ireland and overskudsmad.dk in Denmark (not yet launched). Development or adaptation of IT-systems may be an important part of a systems operator.

Another important task for the systems operator would be to secure funding for redistribution. The current unorganised market for direct redistribution may create competition between charities. For instance, one charity might ask a retail store for payment in exchange for redistribution services, while another charity might do it for free as they have funding from elsewhere. This will likely prevent a sustainable financing system from developing. Furthermore, this does not provide good opportunities for higher service standard towards donors. A common platform will give members better bargaining power with donors and at the same time guarantee better service. Although there are several benefits with developing systems operators, participation of food-serving actors and redistribution actors should be voluntary. Individual set-ups and organisation might function better in some types of activities and contexts. 


\section{Delegated Distribution for Immediate Access}

A recent development within FEBA is called "Delegated Distribution for Immediate Access". This means that a central food bank works more as monitoring entity than an actual redistributor. Some characteristics include:

- Three-party agreements between the donor, the food bank and the foodserving actors. The producers have more faith in the food banks and they thus work as a "quality assurance". Most of the distribution work, however, is done by the charity organisations themselves.

- Training of food-serving actor personnel by the food bank (food safety, hygiene, etc.)

- Food banks organise pick-ups but the food-serving actors perform the actual pick-up. This also quickens the process of redistribution since the food does not have go through a centralized warehouse

Several food banks throughout Europe have begun to establish similar organisational frameworks, acting more like systems operators than simply running logistics. The Lithuanian food bank, Maistobankas, is only actively distributing food in the capital but has signed contracts with charity organisations and institutions throughout the country (approx. 500 charities and 700 institutions). The charities and institutions act as localised redistributin actors and conduct the actual redistribution activities using their local connections, but the work is founded on the standards and reputation of the food bank. This makes for a solid and efficient organisational structure. The food bank offers training and help with administration (e.g. donor contracts), but otherwise does not interfere with the daily work of the local redistribution/food-serving actors. The Estonian food bank, Toidupank, operates under similar conditions, although on a smaller scale.

By discussing shared issues, a systems operator may decide to form a central food bank to provide the logistics service and let the charities focus on their social work. Alternatively, the strong personal bonds that are often present between donors and charities in direct redistribution, in combination with an increase in efficiency due to collaboration, makes a food bank superfluous. Either way, a common voice of the redistributing charities within a region is likely to spread awareness about redistribution and help negotiate with donors and authorities. 


\subsubsection{Common industry initiatives}

A systems operator that coordinates redistribution involving many organisations can be formed by redistribution actors, a regional platform of food-serving actors or a food bank, as discussed above. The systems operator can also be formed by food industry and retail. Current discussions in Norway concern voluntary extended producer responsibility (EPR) of food (see chapter 5.4). An EPR-scheme may be incited by law or voluntarily as an industry initiative, where voluntary agreements can be a way for industry to avoid stricter regulation on food waste management. It would mean that the producer or importer is responsible for proper waste management of the food. Waste prevention by redistribution could then be a very good option for industry.

EPR systems exists for other areas, such as packaging. Instead of every company dealing with their own packaging, common producer responsibility organisations have been established (e.g. Grønt Punkt Norge in Norway and Förpacknings- och tidningsinsamlingen in Sweden). Similar producer responsibility organisations could be formed by food industry and retail, acting as national systems operators for redistribution. This organisation should focus on preventing wood waste as efficiently as possible in the entire industry. Guidelines and agreements could have great impact on potential food donors participating in redistribution. Guidelines made by the industry might increase awareness and legitimacy among donors. Logistics coordination might not be a task for the industry, but funding is an issue that concerns all donors and is crucial for EPR schemes.

\subsubsection{Develop more efficient logistics}

A warehouse is essential to receive and distribute large amounts of food from industry and wholesalers. It is also possible to use them as a common pickup point for food-serving actors, as done by Matsentralen. However, unloading, sorting and distributing from a warehouse requires much labour and time. Small quantities of perishable food are not efficient to transport to a warehouse. Direct redistribution is therefore important to secure fresh food from retail stores and restaurants, where amounts are usually smaller and the "best before" date is close.

It is thus important to enable direct redistribution where it is the fastest and most efficient way of redistributing surplus food to food-serving actors. The actual logistics can be performed by a food bank, as is the case with Allwin. Warehouses should not be seen as mandatory to increase redistribution but rather as a compliment. A food bank can be organised in many different ways, depending on local circumstances. It is important to 
allow this variety of business models. Several of the Swedish organisations examined by Pettersson (2015) lack adequate cold storage and refrigerated transport. This prevents them from receiving perishable food, but lowers operational costs. This may be a consequence of the smallscale operations of these food banks.

The small scale and lack of resources among many redistribution schemes prevents efficient logistics. Whereas promoting food banks over direct redistribution is one way of optimizing, it is important to be open to various understandings of what a food bank is. Having a central warehouse is good for receiving large quantities from producers, but at stores and restaurants surplus food arise continuously and should be distributed immediately to charities. The food banks' job may then be to facilitate planning, cars and drivers to charities and pick-ups from donors as often as needed. What kind of logistics optimization that is needed should be discussed by regional charities and potential donors.

As there will be some competition between organisations over donors, competition should focus on providing the best rather than the cheapest service. Professional distribution companies may be the ones providing the best service to donors, regarding reliability and frequent pickups, as well as to charities. By co-transporting surplus food and other goods, the regular delivery trucks could deliver to a food bank as well as to stores. Charities that are dependent on volunteers or donated money should consider if they can get better value by not conducting the logistics themselves. For larger logistics operations, it is also possible to implement digital route planning or digital tools to link donors and receivers. These should be developed and tested within food banks or systems operators.

\subsubsection{Show the benefits of redistribution}

The trustworthiness of redistribution schemes will affect the willingness to donate food and provide financial support. Partners have to be confident that the food reaches the intended end-consumer and remains high quality. Similarly, in order to increase the willingness to pay for redistribution services, the benefits of donating companies need to be clearer. A first step may be to involve the competent staff that coordinate fundraising for charities.

Several donors to fødevareBanken, for example ARLA, Aarstiderne and Irma Online, proudly promote their partnership. As a partner, they gain a social profile (social sustainability and CSR) as they translate intention into action. The donors promote their partnerships by including 
fødevareBanken in annual events, such as ARLA Food Festival and Barritskov Høstmarked. The experience of Stockholm City Mission is that the donors' employees are glad to be part of an organisation that takes social an environmental responsibility. Several of their partners have experienced the positive feedback from employees on social media etc.

The financial benefits and costs of redistribution are less well known. Calculating the costs of a food bank or food-serving actor and comparing it to the benefits of lower waste management costs and CSR-value, may provide good arguments for getting more funding from donor companies.

\subsubsection{Ensure sustainable income}

The concept of sustainability is central to many actors involved in food redistribution. Actors highlight both social and environmental benefits of redistribution, with the social side especially well defined. It is important to keep the social focus and not make redistribution a kind of waste management. The redistributed food should be safe, attractive and nutritional. Many charities use food aid as a means to ensure continuous contact with its social clients. By making the logistics of redistribution more efficient, the charities are able to focus on this important social work.

The most difficult aspect of sustainability in redistribution today is the economic aspects, as most organisations struggle to get sufficient funding. Better logistics is a key area of development. Better coordination of direct redistribution or better use of vehicles in food banks will lower time and energy needed to transport a given amount of food. For food banks, this means receiving more food, thus enabling economies of scale.

To use volunteers is a way to reduce costs, but may not be an optimal solution for effective redistribution due to the need for reliability. Professional operators might have difficulties in establishing donor agreements when another operator offers to do the service free of charge, even though the professional operator might be more efficient at redistributing food. How suitable a person is for conducting the logistical service of redistribution is of course more dependent on the qualifications of the individual and not if he or she is a volunteer or an employee. However, the larger the operations the higher demands for reliability and management of business. If redistribution is to become a professional business such as other distribution services, it can be argued that the goodwill of volunteers is used to unfairly compete with other logistics 
companies. As redistribution becomes more common, it will eventually become a question of involving more volunteers or creating more jobs.

Whereas costs can be reduced by utilizing vehicles, warehouses and staff more efficiently, the income side is different. Many food-serving actors argue that operations cannot rely too much on donations. These are often difficult to manage and compete with many other social organisations. The opinions differ when asked where the funding should come from, municipalities or businesses. The call for more public funding is often in reference to the social work provided by the food-serving actors, perceived as the municipalities' responsibility. The call for more funding from businesses is in reference to the service provided and that prevention of food waste is the responsibility of those that produce and sell the surplus food. As mentioned by O'Connor et al. (2014), subsidizing redistribution through tax deductions for donors may increase redistributed amounts of food by providing an incentive to donate. However, this policy would not provide any income for food banks or food-serving actors. If authorities would fund or subsidize redistribution, it is important to choose which actors to support.

Food banks and other redistribution actors need to communicate better what they do. By developing efficient logistics and show the benefits to society and donors, the demand for their services will likely increase. By cooperating in local platforms, they can have a better platform when negotiating with donors and authorities. This enables sustainable business models with sufficient funding.

Although cutting costs is important for donors, the main reasons for redistribution should be preventing food waste and providing food to those in need. If companies consider redistribution as a valuable social responsibility, there should be a willingness to pay for a better service. By providing this service or letting professional distribution companies do it, donors should be able to pay more than they do currently.

By discussing the alternative cost of not donating surplus food, redistribution actors and donors may develop more fair models of compensation. Industry and retail stores are usually well aware of the cost of logistics, storage and waste management. When donating large quantities of food, these costs are transferred to the food bank or other actors. By having an open discussion about costs and savings for the respective parties, a better agreement may be made. Redistribution actors may have much to gain from these discussions and negotiations, but it will likely require a new and more business-like approach to redistribution.

The willingness to pay is considered low among potential donors, as they are used to getting the service free of charge. Redistribution is 
higher up in the waste hierarchy than for example animal feed production or anaerobic digestion (biogas production). Therefore, policy instruments could be considered to promote paying for redistribution. If funding by sponsoring is to continue as the main source of income, a raised awareness and a common voice of redistribution and food-serving actors through regional platforms may facilitate more long-term funding.

Yet another possibility is that authorities fund redistribution by sponsoring operations or starting their own. It should be considered, however, that apart from supporting food aid the municipality would also subsidize the waste management of private companies and in some cases compete with private distribution companies. 



\section{Quality assurance: Developing a common platform for quality systems}

This chapter proposes a checklist for assuring food quality during all phases of the redistribution process. It addresses good practices during donation, transporting, storing and distributing of food. The aim with the checklist is to help improve food safety, guarantee adequate food information, prevent food spoilage during redistribution and identify opportunities for food and resource sharing among actors involved in redistribution. As interpretations of food safety legislation varies between countries, this chapter only addresses general considerations. Individual quality assurance systems should be shaped to fit the national context.

\subsection{Reasons for having a system for quality assurance}

Depending on the country, food banks and charity organisations must register themselves as food business operators. As part of the registration, they will need a quality assurance system or an in-house control plan to manage risks and ensure quality. Even if organisations are not required to register as food business operators, it is recommended that they develop an in-house control plan to ensure food safety.

According to the survey (chapter 4.3), the percentage of actors that are registered as food business operators and have quality assurance systems varies between the four countries. This is due to differences in practices, interpretations and instructions from national authorities. About half of the respondents in the survey indicate that they have or are in the process to establishing a system for quality assurance in their organisation. The organisations that have quality assurance systems have followed the guidelines of the national authorities. 
Besides the legal requirements, establishing systems for quality assurance is beneficial since it evokes trust among potential donors. Agreements and contracts with donors that include control and quality assurance might thereby help food banks and organisations get more donations from a larger number of actors.

\subsection{Knowledge and training}

When handling surplus food from donors (e.g. primary producers, retailers, wholesalers or the hospitality sector), redistribution actors must consider the same issues pertaining to food safety and quality as all food business operators. In addition, redistribution actors must also consider issues pertaining to products that are close to their expiration deadlines ("best before" and "use by"). Redistribution actors are usually non-profit and dependent on volunteers and workers that do not necessarily have food safety knowledge and skills.

All workers and volunteers must have basic knowledge of personal hygiene when handling food and general food safety requirements. Although volunteers working with pick-up, transporting and sorting are not required to have formal food safety training, it is commonplace for redistribution actors to facilitate such training for all volunteers.

In fødevareBanken, all new volunteers participate in a mandatory introduction course (presented by the volunteer coordinator) before taking part in the distribution of surplus food. The course includes explanations of work practices related to food safety and basic personal hygiene e.g. requirements in terms of temperature testing, use of gloves/disinfection soap, how to pack the refrigerated trucks, etc. Shortly after the course, the volunteers schedule their first pickup, which is done together with an experienced volunteer. This aims to ensure a safe learning environment.

Operaatio Ruokakassi ry (OR) currently works through thirteen fellowships/parishes that distribute surplus food to social clients. OR is responsible for informing the volunteers of guidelines and requirements implemented by legislation. It is assumed that self-monitoring is handled in compliance with the law and Evira guidelines. It is possible for volunteers to receive a Hygiene Passport (mandatory for people handling unpackaged and easily perishable foods) but currently there are no set procedures for how to ensure quality and food safety in OR. 


\subsection{Labelling}

Food that is released on the market must contain appropriate information to consumers as described in Regulation (EC) No. 1169/2011. All food donated must be suitable for consumption when considering microbiological condition and physical appearance, and the content must be known. Labels must have information about ingredients and allergens, or consumers must be informed in other ways, such as noticeboards. The labelling requirements vary between the four Nordic countries, as described in chapter 5 .

In fødevareBanken, different practices apply to surplus food with different types of expiration date ("use by", "best before") and food without labels. For surplus food with "use by" labels, fødevareBanken only redistributes this food prior to or on the expiration date. For surplus food with "best before" labels, the same practice exists even though fødevareBanken legally is allowed to distribute products that are passed the "best before" date. This practice has been decided upon and approved by fødevareBanken's management and board based on health considerations for the end-users that rely on daily food services. In situations where surplus food is donated without labels (information about expiry date and ingredients), fødevareBanken receives documentation from the donor company stating product name and description, net weight, packing material, shelf life (unopened and opened), storage temperature, ingredient list, nutritional values, potential allergens and expiration date. This documentation is forwarded to the organisations that receive the food.

Operaatio Ruokakassi ry (OR) receives large quantities of surplus food through central storage facilities. This food is most often donated a significant time before the expiration date. This gives more leverage in the further distribution. The on-going financial recession has decreased the amount of food received from any individual donor, but $\mathrm{OR}$ has gotten many more local retailers involved. Although this development puts more pressure on logistics, OR has been able to divide the daily pick-ups between the parishes in a manner that serves their varied distribution schedules. Food received daily from retailers is often close to the expiration date. Therefore, distribution is aimed to happen the same day or the day after at the latest. 


\subsection{Transporting and storing}

The standards for food safety and quality assurance should be maintained during transportation. This can be a challenge with fresh produce that spoils easily, such as fruits and vegetables. Especially temperature requirements are important in this regard. Some of the major redistribution actors have access to freezer cars or refrigerated trucks. The smaller actors can use portable coolers if they do not have access to freezer cars. Hot food can be transported in boxes and insulated bags. The requirements concerning time and temperatures during transportation vary between the four Nordic countries. Several points in the Finnish Evira guidelines address this issue, as described in chapter 5 .

In order to ensure that food is still fit for consumption by the time it reaches the end-consumer, expiration dates should be noticed prior to storing. "First in first out" method should be used in order to help organise shelves and fridges, and special attention should be given to highly perishable foods. It is important to store food in the most appropriate way and at the right temperatures to avoid spoiling and food waste generation at the redistribution actor or the end-user. Sensitive products should be redistributed as soon as possible, e.g. meat, dairy, fruits and vegetables.

It is possible to freeze food for later distribution e.g. if the redistribution actor receives a large amount of a specific product from a donor. The freezing date should be written on the products to ensure that recommended freezing time is kept (e.g. max. 2 months). In some countries, freezing has to happen at the donors' premises prior to donation (see box below).

fødevareBanken is not seen as an end-user under Danish legislation and is therefore not permitted to freeze any food that is not frozen when received from the donors. Compared to its Norwegian sister organisation, Matsentralen, fødevareBanken is therefore not able to prolong the life of e.g. dairy products and meat in situations where the surplus food is unable to reach the end-user within the expiration date.

Operaatio Ruokakassi ry (OR) The parishes that receive food from OR serve the food to end-users the same day, either as meals or in food bags. Most of the parishes do not have capacity to store or freeze the food. OR freezes and stores a significant amount of food for later use. 


\subsection{Donations}

Redistribution activities should be as efficient as possible to avoid food waste and ensure that donated food is suitable for consumption when reaching the end-user. One way to ensure efficiency is through clear agreements between donors, redistributing actors and organisations. Matching supply and demand is the key role of the redistribution actors and this requires good communication routines.

fødevareBanken only distributes surplus food to organisations working for or with socially disadvantaged people. The majority of the organisations receive a weekly delivery, which enables fødevareBanken to schedule the routes beforehand and make timeslots for delivery known to the organisations. Furthermore, the drivers always call the organisation's contact person before arrival to confirm the time of arrival. In cases of ad hoc deliveries, fødevareBanken's manager/assistant in charge of logistics always calls the potential recipient organisation beforehand in order to ensure that the organisation is able to receive the food.

Operaatio Ruokakassi ry (OR) maintains the schedule of the pickups and they are shared in co-operation with other fellowships to match their needs. There has been a strong demand for finding ways to stabilize logistics. This was achieved for the year 2015 through pay subsidies, where OR was able to hire a person to take care of the day-to-day routines. Plain volunteer-based solutions when handling logistics have proven to be impractical and the organisation hopes for a more continuous support.

On the donor side, much can also be done to ensure quality of donations. Retailers and wholesalers that have agreements or contracts with food banks often have clear guidelines for how donations should take place. Donors that donate food directly to food-serving actors on a regular or sporadic basis are also increasingly starting to develop guidelines for this work. The goal is to ensure food safety as well as be able to track donated food if necessary (see chapter 8 for registration and tracing systems). 
The Swedish retailer/wholesaler Axfood has developed a guideline for donating food to social organisations. The guideline highlights the general principles of "first in first out" and provides instructions for how to deal with sorting for donation, registration of food, labelling, storing and donation. The guideline also describes which food categories can be donated under which circumstances.

Axfood retail stores that wish to donate food to charity organisations will first have to pass an audit from Axfood headquarters both relating to the availability of appropriate infrastructure as well as the store's ability to meet financial targets.

Charity organisations will similarly have to pass certain minimum requirements pertaining to capacity and food safety standards in order to receive food from an Axfood store.

The guideline is three pages long and based on the principle "less is more". With the guidelines, Axfood sends a clear signal that donating surplus food is part of their business strategy and that they are a serious partner in both food reduction and social work.

\subsection{Social considerations}

Besides food safety considerations, quality assurance can also refer to the ways in which surplus food is donated and in what social context these activities take place. It is important to distribute food in a way that is sensitive to the situation of the end-users and that does not inflict negative feelings among receivers or donors. In contexts where food bags are handed out or meals are served to a large amount of people, it can sometimes be necessary for the clients to stand in ques. To wait in a public place to receive a food bag or a meal can be stressful and shameful for the client. Having a place inside to wait and drawing numbers rather than queuing can be a way to reduce this problem. This issue is not dealt with any further in this project but could be an important aspect of future studies in order to ensure sustainable practices from a social perspective. 
In Finland, organisations and parishes sometimes give food bags during their appointments with clients. One parish has a mobile shop in form of a bus that they use to deliver food bags directly to clients. The bus stops at several places in a given neighbourhood that only the clients know of. This can reduce stress and feelings of shame among clients.

\subsection{Recommendations}

\subsubsection{Summary}

In the perspective of quality assurance throughout the redistribution process, the following main points can be drawn:

- All food redistributed must be safe for consumption.

- All food business operators can donate surplus food to food banks and charities, incl. primary producers, processing actors, wholesalers, retailers, and the hospitality sector (with some restrictions on food of animal origin between retailers, see chapter 5).

- All types of food can be donated, whether unpacked and packed. Still, some highly perishable foods should be avoided or handled with special care.

- All actors involved in redistribution must follow regulations about cold chain, labels, "use by" dates, storing and hygiene.

- "Best before" labels should be used whenever appropriate, since useby limits redistribution activities.

- Obligatory in-house control plans and education for volunteers and other workers will help food banks and organisations to keep control and prohibit serious mistakes.

- National food safety guidelines would clarify interpretations and liability concerns.

- Redistribution should be operated in a way to decrease discomfort among end-users. 


\subsubsection{Checklist}

The following checklist is aimed at redistribution actors with most of the points addressed especially to food banks and redistribution centres. The checklist can function as a foundation for further work in the individual organisation/company developing an individualised checklist that considers local conditions and concrete regulatory frameworks:

1) Education and in-house control - Ensure appropriate skills among employees/volunteers:

a) Supervise workers and volunteers to ensure that they know basics about safe food handling and good personal hygiene.

b) Write in-house control plan and disseminate information to employees and partners.

c) Ensure a continuous dialogue with employees and volunteers on safety considerations.

d) Brief workers not to work when ill or wounded.

e) Hand washing: Arrange place for washing hands and organise proper clothing like hats, hair restraint and gloves.

f) Follow national food safety authority laws and instructions.

2) Receiving food - Check all food when they are received:

a) Sensory evaluation.

b) "Use by" date is not expired (prior to freezing).

c) Best before products are not spoiled (based on an organoleptic and food safety assessment).

d) All food packages are intact, clean and labelled.

e) If food is not packaged, check to ensure that it is not spoiled.

f) Be aware about very sensitive products e.g. fish products.

g) Frozen food has a label noting the time of freezing.

3) Transporting - Keep the cold/hot chain:

a) Use appropriate and clean vehicles.

b) Plan routes and pick-up-times with donors to decrease transportation needs.

c) If temperature is high, use refrigerated transport, e.g. freezer car, freezer bags or coolers, or collect food in a timely manner to keep the cold chain unbroken. 
d) If transporting hot food, e.g. from restaurants or canteens, make sure that temperatures stay above 60 degrees $\mathrm{C}$.

4) Transparency and traceability - Know your food:

a) Write down types and amounts of food received from each donator in order to know the origin of the food.

b) Register (write down/scan) information about the food delivered to the recipient (food business operator) (e.g. food description, best before/use by date, amount, weight, temperatures kept during transportation) and get signature from the receiver organisation. Register the information centrally - if possible, provide the recipient with a receipt/delivery note.

5) Storing - Store properly to avoid food waste during the redistribution process:

a) If possible, make use of cold rooms (either stationary or portable).

b) Employ "first in first out" method.

6) Redistribution - Ensure efficient redistribution:

a) Plan pick-up and drop-off in collaboration with donors and organisations to match supply and demand.

7) Waste - Waste as little as possible:

a) Redistribute food quickly to avoid products from expiring before reaching the end-consumer.

b) If waste is generated, sort it correctly.

c) Be aware/learn the limit of your own organisation in terms of how much surplus food you are able to redistribute.

d) Make agreements with donors about the types and amounts of food that can be donated.

e) Give feedback to donors on how the surplus food has been used and problems that have occurred during the redistribution process. 



\section{Registration and tracing: Systems for traceability throughout the redistribution process}

The following chapter examines systems for registration and tracing of redistributed food. The aim is to identify why systems for registration and tracing are necessary as well as highlight the advantages and challenges concerning the establishment and use of such systems. Various registration systems are presented and generic recommendations are suggested according to the size and nature of the organisation.

\subsection{Reasons for having a system for registration and tracing}

Food business operators are required by EU legislation to have a system for tracing food in case of withdrawal. Apart from securing traceability, a registration system in connection with redistribution also creates security and credibility between the donor and the receiver. Registration is essential in the relation between retailers and producers, and is a prerequisite for food donations in general. Furthermore, registration systems allow organisations to measure the amount of food being donated and thereby put a number on the effort (both socially, economically and environmentally) as well as the cost savings. The same goes for the donors. Registrations further enable the supermarkets to gain knowledge of the amount and type of food being discarded and thereby gain an overview of what to address in order to prevent or reduce the future generation of food waste as the ultimate goal. 


\subsection{Requirements and legislation}

Regulation on registration regarding redistribution varies between the four Nordic countries. Even though Sweden, Finland and Denmark (as well as Norway to some degree) are subject to the same EU regulations, the interpretation and practises are different, as described in chapter 5. This is due to a perception that redistribution is different from other distribution. This perception also appears in the Commission guidance to Regulation (EC) 178/2002, which states that "Member States should take into consideration the particular situation of charities and donation activities in the context of enforcement and sanctions" (European Parliament 2004b). In general, organisations working with redistribution are in all Nordic countries categorized according to the level of activities including quantities, frequencies and organisation.

Stakeholders redistributing food in Sweden, Finland and Denmark are considered as food business operators and are consequently subject to common EU requirements on traceability. In Norway, food business operators are normally subject to requirements on traceability, but the Norwegian food banks and charities have been defined as end-users and have thereby been exempt from this rule.

Traceability is defined as the ability to trace and follow food, feed and ingredients through all stages of production, processing and distribution. Food business operators have the responsibility to gather documentation that allows the food to be traced one link forward and one link back in the chain. This means that food donors have to register at least to whom they donate food.

As described in chapter 5, each item is registered in Sweden and Denmark, whereas only the receiver of a donation is registered in Finland. This is largely due to the local nature of redistribution in Finland, where long-term storage in food banks is less common. Food delivered to the charities is often served/handed over to the end-user the same day, which makes it similar to a shop that sells food to consumers.

\subsection{Current systems for tracing and registration of food used in redistribution}

The survey presented in chapter 4 shows that only few of the respondents have a registration system for donations. Around $65 \%$ of the respondents do not have a system for registration of food and of those who register $25 \%$ have electronic systems and around $10 \%$ have manual registration. 
Registration is mainly done by food banks and charity organisations that run internal distribution. A few organisations that serve donated food also register donations. Among the respondents, it is more common to register type of food, amount and name of the donor than expiry date. Half of the organisations state that the food authorities do not require registration. Around $60 \%$ of the respondents were local organisations serving food and might therefore not be subject to the regulations. This might be the reason why so few of the respondents have a registration system.

Since redistribution is carried out through both formal and informal channels on a national, regional and local scale, needs and resources vary between the different kinds of redistribution actors. The following sections will contain a description of three different setups and their registration systems across the Nordic countries: food banks, organised local redistribution and informal local redistribution.

\subsubsection{Food banks}

The food banks in the Nordic countries all use different registration systems and register different kinds of information. The following section presents examples of registration systems in Matsentralen, fødevareBanken and Yhteinen pöytä.

\section{Matsentralen}

Registration processes: In Matsentralen, all information is registered manually and later transferred into a computer system. This is done both when products are received from the donor and as products are handed out or delivered to organisations. Three people employed at the warehouse handle the registration, which includes registration of date of delivery, type of product, weight and donor. Furthermore, Matsentralen records temperatures on everything that goes to refrigerators or freezers. If donated products have to go to the cold room, and have not previously been frozen, the products are labelled. Freezing takes three days in accordance with the food safety regulations, and the products are not distributed to recipient organisations earlier than three days after freezing. When delivering donations to organisations, volume and type of product is registered.

Matsentralen always receives an email from the suppliers with information about the donations. Incorrect labelling is often the reason why the products cannot be sold in the stores. In such cases, Matsentralen relabels the products with the correct information, including shelf life. The information can for instance be a flour product that has a one-week shelf life left in accordance with the "best before" labels, but which the supplier 
guarantees will last longer. Matsentralen never distributes products that have passed the "use by" date.

Purpose of registration: Matsentralen registers its donations to gain a complete overview of who delivers, collects and receives the food. Monthly statistics are made for internal use and for the newsletter, which is sent out a few times a year. Most of the donors do not keep track on how much they deliver, hence they use the statistics from Matsentralen as well for their internal work. Matsentralen uses the knowledge on what is in stock to secure a good flow of products. Several times a week emails are sent to all recipients with information about available products.

Documentation of the volume received and handed out is important in order to document the work of Matsentralen. Furthermore, the documentation is used towards getting financial support for operations from governments and sponsors. Records of the amounts distributed to each recipient are also used as a benchmark together with the number of users serviced by the organisation. This provides a safeguard towards misuse of the donated food (e.g. donated food being re-sold for profit or used privately by employees and volunteers).

\section{fødevareBanken}

Registration processes: In 2015, fødevareBanken changed from manual to digital registration with the aim of building up a more efficient registration system. Manual registration and typing in of data was very time consuming and demanded a large amount of resources. fødevareBanken entered into a partnership with IBM in 2013/14 and the result was a traceability study providing the foundation for new digital registration procedures (Escherich \& Nygaard, 2014). Before 2015, registrations were written down during the transport and afterwards typed into an ACCESS database. Now registrations are mainly done with scanners that recognize the products by the barcodes.

In total, fødevareBanken registers name or description of the product, expiry date, weight, amount, temperature, donor, receiver, volunteer and driver. Unlike the previous system, only few of the registrations now have to be typed in manually. For products with barcodes that are already in the system, volunteers only need to type in expiry date and amount. Food with a barcode that is not recognized by the scanner has to be logged and therefore registered with additional information (name and weight). Food items without barcodes are scanned in accordance with a list of predefined product groups. Volunteers, donors and recipient organisations also have barcodes, which further reduces the registration time. 
Data from the scanners is daily transferred to the system, which divides the data into predefined groups, e.g. products non-existent to the system as well as products where data diverge from what is on stock (i.e. errors in amount, expiry date etc.). All new products are logged into the system and diversion are checked and correlated. Delivery notes are emailed to all recipient organisations daily. It is not currently offered as a service to the donors to receive statistics on their deliveries. However, there have been some cases where donors have asked fødevareBanken for such information.

Below is an overview of advantages and disadvantages of manual and digital registration systems:

Table 2: Advantages and disadvantages of manual and digital registration systems

\begin{tabular}{|c|c|c|}
\hline & Manual registration & Digital registration \\
\hline Advantages & $\begin{array}{l}\text { Low operational costs in terms of database } \\
\text { adaptability } \\
\text { Further development of the system by the } \\
\text { IT coordinator due to skills and experience }\end{array}$ & $\begin{array}{l}\text { No triple registration - all data on scanners } \\
\text { are updated on a daily basis } \\
\text { Registration procedures are less time consum- } \\
\text { ing for volunteers } \\
\text { Ability to provide recipient organisations with } \\
\text { delivery notes }\end{array}$ \\
\hline Disadvantages & $\begin{array}{l}\text { Triple registration (warehouse, donor, re- } \\
\text { cipient) } \\
\text { Risk of misinterpretation of data } \\
\text { Time consuming procedure }\end{array}$ & $\begin{array}{l}\text { High investments cost } \\
\text { Increased initial operational cost } \\
\text { Errors in registrations still occur }\end{array}$ \\
\hline
\end{tabular}

Purpose of registration: The Danish food authorities demand registration by the food bank due to the law of traceability. Furthermore, registration provides an overview of the amount of surplus food redistributed, stored in the warehouse as well as its expiry date, which is useful information in the daily operation.

\section{Yhteinen pöytä (Shared Table Project)}

Registration processes: Currently, the Finnish food bank Yhteinen pöytä types in information about donated products to an Excel-based system. The system is developed by the organisation and has therefore not been an external expense for the organisation. Donations are registered with the EAN-code, product type, name of the product, net weight, and retail package quantity and casing dimensions. For dairy products, receiving date, donor and best before date are additionally registered. The organisations also keep track of volunteers involved, organisations who distribute the food delivered by the food bank and number of pickups from the food terminal. Staff at the storage/ warehouse perform the registration. 
Purpose of registration: Registration is mainly for internal use and for the stakeholders. It has not yet been clarified what the food authorities will require from the food bank. As the Finnish food bank has just been started, it is not yet possible to evaluate on the functionality of the current registration system. In addition, it is not yet possible for the organisation to outline specific requirements for a registration system.

\subsubsection{Organised local redistribution}

Organised local redistribution is covering local redistribution from various supermarkets to several local charities with limited storage room/warehouse facilities. The redistribution is often coordinated by a central (local) focal point. This categorization covers most of the established charity organisations operating soup kitchens etc.

In Finland, churches have been organising most of the local redistribution of donated food to local parishes. Registration primarily includes the amount and type of food being donated and delivered to the local centres. This is done in order to keep track of the work. One of the organisations in the survey does not perform any registration that secures traceability. Some of the centres register the food by an estimated value instead of by amount, which gives a less exact overview. Similarly, a lack of registration of what the parishes receive from local retailers creates a gap in the total registration.

In Sweden, the internal food bank of the Salvation Army is in charge of all donated food for 16 different locations. Content and type of each product/package, the value and weight as well as the receiver is registered on a laptop in an Excel-sheet. The expiry date is not registered but examined. All chilled foodstuffs are distributed within a day. Electronic registrations make it easy to do statistics and speed up the registration process. The Salvation Army would prefer to use hand scanners instead of a laptop, but this requires an IT-system and an investment. 


\section{NOFO-Foodtrack}

NOFO-foodtrack is an app developed by the Danish regional food bank, Nordjydsk Fødevareoverskud. The app is developed using free development tools from Google and runs on all Android platforms.

Registration is done during the transportation. When all items are registered in the app, a report is sent to the e-mail address of the organisation. Depending on the volume and how the products are received and delivered it may be necessary to make some manual corrections in order to make the amount consistent $(\mathrm{kg}$ received $=\mathrm{kg}$ delivered). The corrections are done in an Excel-sheet, where the report from the app is imported directly without manual entry.

In Denmark, there is no tradition of organised local redistribution carried out by the charity organisations. Instead, this work has been carried out as direct local distribution. Currently a new platform for food donation is being developed. The website overskudsmad.dk creates contact between food companies, retailers, catering centres etc. and local charity organisations. The platform replaces the third party, e.g. a food bank, and thus eliminates the requirements of traceability. By using the platform for donations, both donor, receiver, amount and type of food (and in some cases expiry date) is automatically registered in the system. Information from the donors' IT-systems is transferred to the website. If the donor registers the expiry date, it will automatically appear in the registration system of overskudsmad.dk as well. In this way, the registration is done and shared by the donors, either manually or through their own registration system.

"Food companies, retailers and others who want to donate food can sign up in our system and create donations where they indicate what is donated, how much and where, when and how it can be collected. Registered organisations in the local area will then receive an e-mail and using our website indicate whether they would like the food. If they want to receive the food all they have to do is to collect it and afterwards offer meals to needy citizens."

Overskudsmad.dk 


\subsubsection{Local redistribution}

Local redistribution, e.g. from a supermarket to a charity organisation, must live up to the traceability requirements pertaining to distribution of food between food business operators. This is not the case in Norway, since charity organisations are seen as end-users. Traceability rules do not apply to food redistribution to end-users (e.g. from a food-serving actor to a social client). Therefore, in Denmark, Finland and Sweden, foodserving actors are required to register what they receive from donors but not what they serve/deliver to social clients.

Local redistribution occurs in different ways and donors and foodserving actors have different systems for complying with traceability requirements.

As described in the previous chapter, the Swedish retail/wholesaler Axfood has developed guidelines for food donation that their stores can use to ensure food safety during donation processes. Axfood has introduced a donation category in their registration system, which makes registration simple for employees. The registered information is shared with the receiving organisation to ensure traceability. When developing routines and systems for donation, it has been important for Axfood that donating does not add any more work for the retail store employees than when discarding the food. If registration of donations is more time consuming than discarding, the individual retail stores will likely not prioritize donating.

The Swedish retail chain Willys is part of Axfood and must therefore comply with the Axfood guidelines for donations to social organisations. Willys has established contact with local organisations that receive food directly from the local Willy stores. Employees at the shops register all surplus products and indicate the reasons for either discarding or donating. When charity organisations come to pick up the food, temperature is controlled and registered. In this way, Willys is able to document what has happened to the donated products and keep track of the food loss of the individual stores.

Another Swedish retailer, ICA, registers the food that is donated to the Salvation Army, but due to the traceability requirements of the Salvation Army, the data is registered again by the organisation.

The Norwegian retailer organisation Norgesgruppen is also doing separate registration of food being wasted or donated and they share this information with the public through the ForMat research project.

In Denmark, the local organisation Kirkens Korshær in Esbjerg receives $60-70 \%$ of the food directly from donors (Hanssen et al. 2015). 
They have no registration of the donated food, mainly due to lack of resources. Donated food with a short shelf life is used on a day-to-day basis and is therefore not being stored. The short shelf life means that involvement of a third party, like a food bank, and dealing with transport and storage would not be possible. A considerable part of what the organisation receives is prepared food, which has been labelled and frozen by the donor.

\subsection{General challenges}

A common challenge for all organisations working with redistribution is lack of time and resources to register the donations. In Operaatio Ruokakassi, manual registration of type and amount of food is estimated to take up to three hours a day. Matsentralen uses a minimum of two hours per day for activities related to registration, while the Swedish Salvation Army estimates that they use $1 / 6$ of their time on registration. In comparison, the new Finnish food bank uses approximately 20 minutes a day on registration.

The workforce in the redistributing organisations is often voluntary and the staff turnover is high. This requires extra resources for training. Changing staff might as well increase the risk of mistakes or inconsistent registrations, which afterwards need to be manually corrected.

Currently no general registration system is developed (and freely available). Development and purchase of a customized system and the related devices are big investments for organisations that often run on low budgets. The organisations investigated in this study all "invented" their own systems.

The development and implementation of a registration system requires resources and skills, hence a common system could help save time and secure better data. The following section will list up recommendations for registration systems in order to ease the work with developing registration systems.

\subsection{Recommendations}

Registration takes up many resources in the organisations operating the redistribution of surplus food in the Nordic countries. The donors are already carrying out a lot of the registration needed, but willingness to share data is a well-known barrier. As described above, there are some 
examples of collaborations between donors and receives. Collaboration in developing systems for shared registration/information between donor and receiver could make registration more efficient.

Due to the considerable differences in especially resources and capacity/size between the above-mentioned types of redistribution, one model for registration would not be suitable for all. Therefore, a list of recommendations will be given to each of the three types of redistribution.

\subsubsection{Food banks}

\section{Characteristics}

- Large volumes of food.

- Many donors and receivers.

- Warehouse facilities.

- Professional administration.

- Large number and turnover of volunteers.

- Limited budgets.

- Traceability requirements.

\section{Recommendations}

Due to the quantities of food redistributed and the storing of food at warehouse facilities, it is essential that the registration system is securing the food safety of the food in storage.

Registration systems for the organised food banks should:

- Limit the daily resources used on registration.

- Secure traceability.

- Provide a "live" overview of food in stock/storage.

- Enable easy data sharing of food in storage with receiving organisations.

- Generate statistics.

- Be simple to use and learn for volunteers. 


\subsubsection{Organised local redistribution}

\section{Characteristics}

- Varied amounts of food.

- Less donors and receivers.

- Non or limited storage.

- Primarily day-to-day distribution.

- Traceability requirements are less consistently implemented.

\section{Recommendations}

Due to the lack of storage capacity, most of the organised local redistribution depend on good communication with donors and receivers on what is donated and who has the corresponding need. It is essential to create a system that easily matches supply and demand, but at the same time ensures the quality of the donated food and that donations are collected.

The registration systems for organised local redistribution should:

- Secure traceability (even though it might not be required by food authorities).

- Allow donors to automatically share information about the food with the various receiving organisations.

- Create certainty for the donors that the food is picked up from the donors and delivered to approved receivers.

- Require few resources by the organisation facilitating the contact.

\subsubsection{Local redistribution (1:1)}

\section{Characteristics}

- Small amounts of food.

- Few and often permanent donors.

- Few volunteers and resources (often dependent on few dedicated volunteers).

- No storage.

- Day to day use of donations. 
- Traceability not required, since they are regarded as end-users.

\section{Recommendations}

Due to the small amounts of food and lack of resources, it might not be realistic to have a registration system. Nevertheless, it is recommended that the organisations make some registrations in order to document the work carried out and keep track of the flow through the organisation. 


\section{Main recommendations}

The following main recommendations have been identified based on the four themes in the chapters above as well as through the two workshops held in April and November 2015. Workshop participants represented central actor types from all four Nordic countries. Preliminary results were presented and discussed among participants in groups and in plenary discussion. The research institutions are responsible for the final recommendations. The main recommendations are divided based on the three main actors addressed in this report: 1) redistribution and foodserving actors, 2) donors and 3) authorities.

\subsection{Main recommendations for redistribution and food-serving actors}

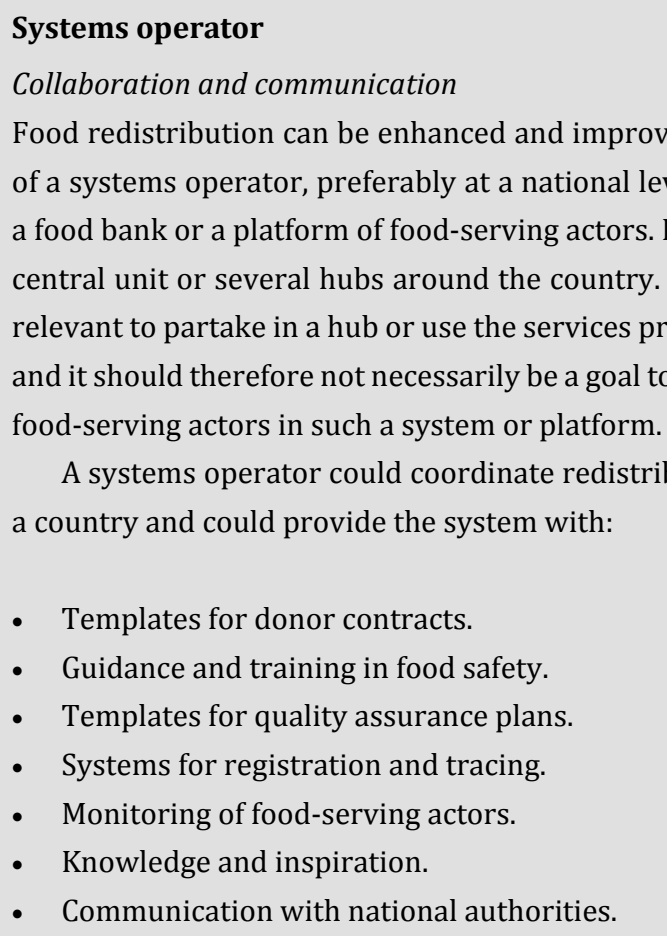
a country and could provide the system with:

- Templates for donor contracts.

- Guidance and training in food safety.

- Templates for quality assurance plans.

- Systems for registration and tracing.

- Monitoring of food-serving actors.

- Knowledge and inspiration.

- Communication with national authorities.

A systems operator could coordinate redistribution activities in a region or 
- Information directed at the public.

In cases where distances between actors are short, a systems operator or a hub may also function as an infrastructure unit, allowing actors to share vehicles and other important equipment for transporting and storing food.

Collaborating with a systems operator or being a member of a hub can potentially strengthen credibility and legitimize the redistribution activities of food-serving actors as well as donors.

The establishment of a systems operator could potentially be funded through regional or national funding. The further financing could be done collaboratively by the entities benefitting from the service: food-serving actors, donors and authorities.

\section{Guidelines}

Food safety, transparency, and efficiency

Every actor involved in food redistribution should have written guidelines describing steps to ensure food safety through training, quality control systems and systems for registration and tracing of food. See chapters 7 and 8 for concrete suggestions for content of guidelines.

Guidelines are especially important for actors that do not have an easy way to communicate with local authorities. Guidelines will further reduce time authorities spend communicating with actors on individual questions pertaining to general food safety regulation, which is costly for both authorities and the individual actors.

Guidelines should be developed in collaboration with donors and authorities to assure application to the donor-specific context as well as compliance with food safety regulation. This collaboration is also likely to facilitate knowledge sharing and ease communication later in the donation process.

Guidelines should build on existing guidelines and experiences from actors involved in redistribution. See the separate appendices for the Evira Guidelines and the Axfood Guidelines. However, it is important to recognize that that is no "one size fits all", and it will be necessary for actors to develop systems and guidelines that are suitable for their organisational context. 


\section{Funding}

Creating standards and services

Funding is the big question mark in food redistribution. Who should pay? The answer will vary depending on the kind of redistribution con-ducted and the business model of the particular actor. Because of the history of redistribution as something done by charity organisations and volunteers, defining the service and setting the price in a market context is challenging for most redistribution actors.

Ideally, redistribution activities are to be regarded as services that should be funded by all actors benefitting from such activities:

- Donors: food redistribution represents an alternative to waste management service for donors. In most cases, food that is redistributed would otherwise have presented a cost in disposal fees. Donors should thus pay for this service on market-like terms.

- National and local authorities: food redistribution provides a substantial contribution to the social and physical welfare of socially disadvantaged people. In addition, reducing food waste simultaneously reduces the environmental impact of both food production and food waste management. Social and environmental authorities should therefore see redistribution as a strategic tool and provide adequate funding accordingly.

- Food-serving actors: Many food-serving actors receive most or all of their food from redistribution actors. This service should be paid for to the extent the food-serving actors are able to do so.

Redistribution actors are recommended to define clearly the various services provided by their activities to further entice relevant entities to support these activities. This also applies to food-serving actors in relation to social authorities.

\subsection{Main recommendations for donors}

\section{Donation as CSR}

Reducing surplus food and preventing food waste

Taking corporate social responsibility (CSR) is becoming an integrated part of running a business in the 21st Century. In the food sector, this means ensuring that the food products are produced, transported and consumed in a way that supports environmental, economic and social sustainability. In the context of food waste, it means a) to limit the amounts of surplus food, and b) to make sure that any surplus 
food suit-able for human consumption is redistributed to socially disadvantaged people, e.g. through food banks and charity organisations.

Donating surplus food to redistribution and food-serving actors can be part of a CSR strategy and can provide a valuable competitive ad-vantage in an increasingly critical consumer environment.

In some cases, it may be appropriate for donors to take collective action in redistribution through an extended producer responsibility (EPR) system in collaboration with both organisations and authorities. In an EPR system, member businesses would set targets for food reduction and fund reduction measures through membership fees. Such systems exist for e.g. food packaging (in Norway) and textiles (in France).

\section{Guidelines}

Food safety, transparency, and efficiency

Food safety is of high importance for donors, charities and for the end-consumers. For donors this is also important in a publicity perspective. The best way to ensure food safety is to have clear guidelines for how and under which circumstances food is donated. See the separate appendices for the Evira Guidelines and the Axfood Guidelines.

Guidelines and systems for quality assurance and food registration allows donors to gain knowledge of the amount and type of food being discarded. Thereby donors gain an overview of what to address in order to reach the goal of preventing or greatly reducing food waste. Whole-salers and retailers already have systems for registration, so it may only be a matter of adding yet another category for donated food into existing systems.

Guidelines should be developed in collaboration with redistribution and food-serving actors as well as authorities in order to ensure applicability and compliance with food safety regulations. Also, a high degree of collaboration at the early stages of food donation practices will likely ensure efficient use of resources and limit misunderstandings be-tween actors, which can lead to food waste (e.g. when, where and how to pick up/deliver food).

Donating food should be done at a regular basis under agreements and/or contracts with redistribution and food-serving actors. A contract describing expectations and commitments between donor and receiver further helps ensure food safety by establishing a trust relationship be-tween actors and making the donation process transparent. 


\section{Funding}

Redistribution as waste management service

Redistribution activities cost money. Redistribution actors transport and store large quantities of food while ensuring food safety from donor to food-serving actors. While some donors pay for this service, e.g. via annual membership fees or per pick-up/kg of food, income does generally not cover expenses for the redistribution actors.

As with general waste management, redistribution is a service and should thus be seen as such by donors. Although the donated food has a value to the end-users, this should not be calculated as a monetary value that donors give and that therefore frees them for any other financing of the operation. Since surplus food in most cases would have otherwise been discarded, and thereby been an expense to the donor, donating the food instead should be seen as a saving for the donor. As such, donation frees funds otherwise spent on waste management. It is recommended that some of these funds go towards financing redistribution activities. How this is organised should be decided upon in collaboration between donors and redistribution actors.

\subsection{Main recommendations for authorities}

\section{Prioritizing redistribution}

Defining food waste in the waste hierarchy

Food waste reduction is a goal for the Nordic governments as well as in the EU. In the EU, waste hierarchy it is made clear that the general preferred order of intervention is prevention, preparing for re-use, recycling, recovery and disposal. It is however unclear which concrete interventions are preferable in a food waste prevention perspective.

It should be made clear through political initiatives and funding schemes that redistribution of food is higher in the waste hierarchy than other interventions, e.g. biogas production. In Belgium and the UK, the following prioritization has been suggested: prevention, redistribution to humans, feeding to animals, energy or nutrient recovery by methods such as Anaerobic Digestion (AD), composting, and landfilling.

Ways to underline this prioritization can be through financial incentives for donation of food. For instance, allowing donors to reduce the value of food items to zero before donation in order to avoid paying VAT on the products. This has recently been done in Denmark. 
It is also recommended that authorities provide instructions for appropriate expiration labelling. In some countries, like Finland, food producers and wholesalers are required to apply the "use by" label on the majority of products. This greatly limits the ability of these actors to donate food. In countries where "best before" has become more widely used, like Norway, donations have increased. It is considered possible to enhance redistribution of food in this way, while simultaneously ensuring food safety.

\section{Guidelines}

Food safety, transparency, and efficiency

Food redistribution activities have been going on in the Nordic countries for several decades, but for the most part, it has occurred "under the radar". This was both a result of the previous lack of interest for such activities among the public, but also due to uncertainties among actors involved in redistribution as to the regulations governing such activities.

The national food safety authorities can play an active role in developing guidelines that clearly state the food safety legislation and regulations and how this pertains to the different types of actors involved in food redistribution. See the separate appendices for the Evira Guidelines and the Axfood Guidelines. In countries where industry-led guidelines are more favourable, it is recommended that food safety authorities support such efforts and inform the process from a legal standpoint.

National food safety authorities are recommended to communicate with other Nordic countries on how to interpret EU-legislation in a way that facilitates and supports donation and redistribution activities while ensuring food safety.

\section{Funding}

Social and environmental services

Food redistribution can be seen as both social and environmental interventions and should be valued as such by environmental, social and food authorities. Some redistribution and food-serving actors are supported by local and national authorities, but funding is often not sufficient to cover expenses.

Funding does not only cover operation costs but provides the financial capacity to establish efficient and comprehensive systems for quality assurance 
and registration in order to ensure food safety throughout the redistribution process.

Local and national authorities are recommended to actively support actors engaged in food redistribution through steady and considerable funding. One way to organise such funding could be through the establishment of a systems operator that ensures food safety and provides a common platform for actors involved in redistribution, e.g. for efficient communication with food safety authorities. 



\section{References}

Alexander, C. \& Smaje, C. (2008). Surplus retail food redistribution: An analysis of a third sector model. Resour. Conserv. Recycl, Vol. 52, 1290-1298.

Aschemann-Witzel, J., de Hooge, I., Amani, P., Bech-Larsen, T. \& Gustavsson, J. (2015). Consumers and food waste - a review of research approaches and findings on point of purchase and in-household consumer behavior. Paper prepared for presentation at the EAAE.AAEA Joint Seminar "Consumer Behavior in a Changing World: Food, Culture, Society".

Betz, A., Buchli, J., Göbel, C. \& Müller, C. (2015). Food waste in the Swiss food service industry - Magnitude and potential for reduction. Waste Management, Vol. 35, 218-226.

Capodistrias, P.V. (2015). Reducing food waste through direct surplus food redistribution: The Norwegian case. Master Thesis. Norwegian University of Life Sciences. Ås, Norway.

Escherich K. \& Nygaard, T. J. (2014). Traceability study fødevareBanken, IBM.

European Commission (2015a). Closing the loop: Commission adopts ambitious new Circular Economy Package to boost competitiveness, create jobs and generate sustainable growth. Press release, Brussels 2 December 2015, http://europa.eu/ rapid/press-release_IP-15-6203_en.htm, accessed on 3 December 2015.

European Commission (2015b). EU actions against food waste, http://ec.europa.eu/ food/satefy/food_waste/eu_actions/index_en.htm, accessed on 24 September 2015.

European Parliament (2015). Resource efficiency: moving towards a circular economy. European Parliament resolution of 9 July 2015, 2014/2208(INI).

European Parliament (2014). Regulation (EC) No. 223/2014, Article 26, 2(d), http://eur-lex.europa.eu/legal-content/EN/TXT/HTML/?uri=CELEX:32014R0223 \&from $=\mathrm{EN}$

European Parliament (2013). Joint answer given by Mr Šemeta on behalf of the Commission. Written questions: E-003730/13, E-002939/13, http://www.europarl.europa.eu/sides/getAllAnswers.do?reference=E-2013002939\&language $=\mathrm{EN}$

European Parliament (2006). Council Directive 2006/112/EC of 28 November 2006 on the common system of value added tax, http://eur-lex.europa.eu/legal-content/ EN/TXT/?uri=URISERV:131057

European Parliament (2004a). Regulation (EC) No. 852/2004 of the European Parliament and of the Council of 29 April 2004 on the hygiene of foodstuffs, (9), http://eur-lex.europa.eu/legal-content/EN/TXT/?uri=uriserv: OJ.L_.2004.226.01.0003.01.ENG

European Parliament (2004b). Guidance on the implementation of articles 11, 12, $16,17,18,19$ and 20 of Regulation (EC) No. 178/2002 on general food law. Article 18, II.3.1. ii, http://ec.europa.eu/food/food/foodlaw/guidance/ guidance_rev_7_en.pdf 
European Parliament (2002). Regulation (EC) No. 178/2002 of the European Parliament and of the Council of 28 January 2002 laying down the general principles and requirements of food law, establishing the European Food Safety Authority and laying down procedures in matters of food safety, Article 3.2, http://eur-lex. europa.eu/legal-content/EN/TXT/?uri=celex:32002R0178

Evira (2013). Foodstuffs donated to food aid. 21.05.2013. Instructions 16035/1, http://www.evira.fi/files/attachments/en/food/manufacture_and_sales/ruokaapuohje_16035_2013_en_final.pdf

FAO (2014). Mitigation of food wastage. Societal costs and benefits, Food and Agricultural Organisation of the United Nations.

FEBA (2015). Social impact indicators. http://www.eurofoodbank.eu/about-us/ social-impact-indicators, accessed on 29 September 2015.

FEBA (2007). How to create a food bank? Bourg-la-Reine, France.

Graham-Rowe, E., Jessop, D.C. \& Sparks, P. (2015). Predicting household food waste reduction using an extended theory of planning behavior. Resource, Conservation and Recycling, Vol. 101, pp. 194-202.

Halloran, A., Clement, J., Kornum, N., Bucatariu, C. \& Magid, J. (2014). Addressing food waste reduction in Denmark. Food Policy, Vol. 49, pp. 294-301.

Hanssen, O.J. (2015). Må jeg virkelig kaste all denne maten? Kronikk. Fredrikstad Blad, 06.08.15.

Hanssen, O.J., Ekegren, P., Gram-Hanssen, I., Korpela, P., Langevad-Clifforth, N., SkovOlsen, K., Silvennoinen, K., Stare, M., Stenmarck, Å. \& Svanes, E. (2015). Food Redistribution in the Nordic Region. Experiences and results from a pilot study. TemaNord, 562. Nordic Council of Ministers.

Katajajuuri, J-M., Silvennoinen, K., Hartikainen, H., Heikkilä, L. \& Reinikainen, A. (2014). Food waste in the Finnish food chain. Journal of Cleaner Production, Vol. 73, pp. 322-329.

Landbrug \& Fødevarer (2015). Madspild i Danmark. Et overblik over undersøgelser og igangværende projekter om madspild i Danmark. 23 September 2015. Landbrug \& Fødevarer, https://www.lf.dk/Tal_og_Analyser/Analyser/Forbrug_og_detail.aspx

László, A. (2013). Europe's social crisis: Is there a way out? Presentation given on April 12, 2013 at Max Planck Institute of Social Law and Social Policy, Munich, http://europa.eu/rapid/press-release_SPEECH-13-309_en.htm

Munesue, Y., Masui, T. \& Fushima, T. (2015). The effects of reducing food losses and food waste on global food insecurity, natural resources, and greenhouse gas emissions. Environmental Economics \& Policy Studies, Vol. 17, Issue 1, pp. 43-77.

O'Connor, C., Gheoldus, M. \& Jan, O. (2014). Comparative Study on EU member states' legislation and practices on food donation. Final report. European Economic and Social Committee.

Papargyropoulou, E., Lazono, R., Steinberger, J.K., Wright, N. \& bin Ujang, Z. (2014). Journal of Cleaner Production, Vol. 76, pp. 106-115.

Parizeau, K., von Massow, M. \& Martin, R. (2015). Household-level dynamics of food waste production and related beliefs, attitudes, and behaviours in Guelph, Ontario. Waste Management, Vol. 35, pp. 207-217.

Petersen, J.H. \& Koldborg, S. (2014). Momsforvirring spænder ben for madgenbrugsbutik. Danmarks Radio Nyheder, 25 November 2014, https://www.dr.dk/nyheder/ penge/momsforvirring-spaender-ben-madgenbrugsbutik, accessed on 10 November 2015 . 
Pettersson, S. (2015). Minskat matsvinn genom välgörenhet - En studie om matbanker och liknande verksamheter. Master's Thesis. Lund University, Environmental and Energy Systems Studies. Lund, Sweden.

Quested, T.E., Parry, A.D., Easteal, S. \& Swannell, R. (2011). Food and drink waste from households in the UK. Nutrition Bulletin, Vol 36, pp. 460-467.

Regjeringen (2015). Intensjonsavtale om reduksjon av matsvinn, https://www.regjeringen.no/contentassets/e54f030bda3f488d8a295cd0078c4fcb/matsvinn.pdf, accessed on 21 October 2015.

Silvennoinen, K., Heikkilä, L., Katajajuuri, J-M. \& Reinikainen, A. (2015). Food waste volume and origin: Case studies in the Finnish food service sector. Waste Management, Available online 26 September 2015, In Press.

SKAT (2015). Moms - udlevering af overskudsfødevarer - styresignal. SKM2015.664.SKAT, October 23 2015, http://www.skat.dk/skat.aspx?oID=2179524, accessed on December 212015.

Williams, I.D., Schneider, F. \& Syversen, F. (2015). The "food waste challenge" can be solved. Editorial. Waste Management, Vol. 41, pp. 1-2. 



\section{Sammendrag på dansk}

I denne rapport opsummeres resultaterne fra fase II i det nordiske projekt om redistribution af fødevarer, The Nordic Food Redistribution Project. Projektet er igangsat af Nordisk Ministerråd som del af grøn vækst initiativet fra de nordiske statsministre, "The Nordic Region - leading in green growth", og er finansieret gennem Fødevarer og Landbrugsprogrammet.

Projektet belyser, hvordan de nordiske lande organiserer og håndterer redistribution af fødevarer, samt hvordan sådanne aktiviteter kan styrkes samtidig med at fødevaresikkerheden sikres gennem hele værdikæden. I dette projekt ses redistribution af fødevarer hovedsagelig i lyset af de miljømæssige problemstillinger som er forbundet med madspild. Redistribution af fødevarer har dog også væsentlige sociale og økonomiske komponenter, og det er derfor oplagt at se på denne type aktivitet som noget, der understøtter en bæredygtig udvikling generelt - i Norden og globalt.

I første fase af projektet blev barrierer og mulige løsninger identificeret. Målet med fase to har været at undersøge disse løsningsforslag nærmere og identificere "best practices" som har mulighed for at understøtte den videre udvikling. Et centralt tema i projektet har været, hvordan man kan udvikle økonomisk bæredygtige organisationsgrundlag for redistributions-aktiviteterne, så disse kan blive et seriøst bidrag til reduktionen af madspild i de nordiske lande.

På baggrund af resultaterne fra første fase har fase to fokuseret på følgende fire aktiviteter:

- Beskrive og evaluere lovværket for direkte og central redistribution i de nordiske lande og identificere "best practices" modeller.

- Udvikle organisationsmodeller for lokal og central redistribution, hvor fødevarebanker kan agere som redistributions-centre.

- Udvikle grundlag for kvalitetssikringssystemer til brug i redistributionen i de nordiske lande.

- Udvikle systemer for registrering og sporbarhed af fødevarer. 
Aktiviteterne i de fire nordiske lande (Danmark, Finland, Norge og Sverige) er gennemført af nationale forskningsinstitutioner i samarbejde med nationale fødevaremyndigheder og aktører som er direkte involveret i redistribution, hovedsagelig fødevarebanker og velgørenhedsorganisationer. Samarbejde med andre relevante aktører er blevet muliggjort gennem to workshops, som blev afholdt i Oslo og Gøteborg i løbet af 2015. Forskningsinstitutionerne er ansvarlige for rapportens endelige anbefalinger.

Der er forskel på de lokale og nationale kontekster, og der findes derfor ikke én enkelt model for redistribution af fødevarer. Anbefalingerne som præsenteres i denne rapport skal derfor ses i lyset af lokale forhold.

Hovedanbefalingerne henvender sig til tre centrale aktører:

\section{Aktører som redistribuerer og serverer overskudsmad (inkl.}

fødevarebanker, velgørenhedsorganisationer og andre brugere af overskudsmad)

- Etablere national/regional platform eller central operatør til at sikre samarbejde mellem de involverede aktører samt sikre effektiv brug af de tilgængelige ressourcer.

- Udvikle retningslinjer for redistributions-aktiviteter, inkl. kvalitetssikring or registrering, for at sikre fødevaresikkerheden og øge tilliden blandt donorer og befolkningerne.

- Sikre en bæredygtig finansiering af redistributions-aktiviteterne, bl.a. igennem at prissætte tjenesterne og øge kommunikationsindsatsen.

\section{Donorer (inkl. alle fødevarevirksomheder som donorer eller kan} donere overskudsmad)

- Inkorporere donation af overskudsmad som del af virksomhedens CSR strategi med det formål at være på forkant med forbrugernes øgede forventninger og fremtidige lovmæssige krav.

- Udvikle retningslinjer for donation af overskudsmad i samarbejde med redistributions-aktører og myndigheder for at sikre fødevaresikkerheden og undgå unødvendig madspild i redistributions-kæden.

- Bidrage til driften af redistributions-aktørerne gennem betaling for de tjenester som redistributions-aktørerne udfører i form af f.eks. medlemskab eller betaling pr. afhentning. 
Myndigheder (inkl. lokale, regionale og nationale social-, miljø- og affaldsmyndigheder)

- Prioritere redistribution af fødevarer i affaldshierarkiet og anse redistribution som værktøj til at reducere fødevareindustriens miljøpåvirkning, øge den sociale sikkerhed for udsatte befolkningsgrupper samt reducere omkostninger forbundet med virksomheders og lokale myndigheders affaldshåndtering.

- Udvikle retningslinjer for fødevaresikkerhed i samarbejde med redistributions-aktører og donorer.

- Bidrage til en stabil finansiering af redistributions-aktører på baggrund af de miljømæssige og sociale tjenester de tilbyder.

Det anbefales yderligere, at projektet udvides med en tredje fase, med det formål at implementere nogle af de ovennævnte anbefalinger i samarbejde med lokale redistributions-aktører i de fire lande. Dette vil bidrage til en dybere forståelse af, hvordan redistribution af fødevarer kan øges og forbedres i de nordiske lande. 



\section{Appendices}

\section{Appendix I: Participating organisations and individuals}

\section{Comments for the report}

\section{Finland}

- The Finnish Food Safety Authorities, Pirjo Korpela.

- Operaatio Ruokakassi, Janina Rosten and Merkku Järvenpää.

- Pelastusarmeija, Saga Lippo.

- Yhteinen pöytä-project, Hanna Kuisma and Jukka Turunen.

\section{Denmark}

- The Danish Veterinary \& Food Administration, Rikke Karlsson.

- fødevareBanken, Henrik Olsen, Kirstine Nielsen and Leif Romanoff.

- Kirkens Korshær Esbjerg, Peter Starup.

- Nordjyst Fødevareoverskud, Bente Schjødt and Jesús Pérez.

- Overskudsmad.dk, Thomas Fremming.

\section{Norway}

- Matsentralen, Linn Weiergang.

- The Norwegian Food Safety Authority, Atle Wold.

\section{Sweden}

- Allwin, Simon Eisner.

- Willys, Anna Åhnberg.

- Salvation Army Stockholm, Isac Felixon.

- Stockholm City Mission, Anne Lunde Dinesen.

- The Swedish National Food Agency, Gustaf Hammerlof. 


\section{Survey respondents}

\section{Finland}

- Korson Ruokapalvelu ry, Marja Kauhanen.

- Operaatio Ruokakassi, Lottariina Hämäläinen.

- Salvation Army, Saga Lippo.

- Turku Street Mission ry, Jukka Silvola.

- Vantaan Apuraide ry, Jarno Eskelinen.

- Yhteinen pöytä-project, Hanna Kuisma.

\section{Denmark}

- Center for Socialt Udsatte Næstved, Lise Rasmussen.

- Den Sociale Café Fristedet.

- Fundamentet, Morten Kjær Egebjerg.

- fødevareBanken, Henrik Olsen and Leif Romanoff.

- Kirkens Korshær, Jette Sølvhøj.

- Kirkens Korshær Slagelse, Hanne Merete Pedersen.

- Kvindehjemmet, Birgit Søderberg.

- Muhabet, Najib Haddar.

- Overskudsmad.dk, Thomas Fremming.

- Salvation Army, Per Henrik Jensen.

- Salvation Army Nakskov, Finn Heyn.

- Salvation Army Vejle, Kirsten Rasmussen.

\section{Norway}

- Frelsesarmeen Kristiansand, Kolbjørn Ørsnes.

- Frelsesarmeen rusomsorg Hveita, May Helen Skjærvø.

- Frelsesarmeen Torp, Kari Agathe Lorentzen.

- Kirkens Bymisjon, Anne-Marie Kvarme.

- Kirkens Bymisjon Trondheim, Jon Henrik Gulbrandsen.

\section{Sweden}

- Allwin, Simon Eisner.

- Charity of Food, Magnus Hansson.

- Stockholm City Mission, Anne Lunde Dinesen and Maria Malm.

- Svenska Matbanken, BeaunYves Sheila Fungula. 


\section{Appendix II: Survey questions}

\section{Survey questions}

\section{Redistribution of food in the Nordic Region - Phase II}

The main scope of this survey is to get an overview of how organisations being involved in redistribution of surplus food in the Nordic region have organized their activities, which types of quality systems they are using, how they are registering and tracing food being donated and if they have any experiences with food safety authorities. The same survey is used all over the Nordic region, which is the reason why all questions are in English.

We will kindly ask you to answer the questions as soon as possible and no later than April 20, 2015.

1. Contact information:

a. Name of organisation.

b. Name of contact.

c. County.

d. Email address.

e. Phone number.

\section{Organisation of redistribution}

2. Do you have an annual report or other documents presenting your organisation and its operation, that you would be willing to share with us?
a. Yes.
b. No.

3. What is the role and geographic scale of your organisation in food redistribution?

a. National food bank - open redistribution to several organisations.

b. Regional/local food bank - open redistribution to several organisations.

c. Internal logistic center for redistribution of surplus food in own charity organisation.

d. Serving food to social clients/delivering food bags based on donated food. 


\section{National organisations}

4. Which are the main sources of donated food for your organisation?
a. Food producers.
b. Wholesalers.
c. Retail shops.

5. Does your organisation have agreements with donor organisations nationally about regular donations?
a. Yes, many.
b. Quite a few.
c. No collaboration.

6. Does your organisation collaborate with other redistribution organisations nationally?
a. Yes, to a high extent.
b. Some collaboration.
c. No collaboration.

7. Does your organisation compete with other organisations nationally for surplus food?
a. There is a high level of competition.
b. There is some competition.
c. There is limited competition.
d. There is no competition.

8. How is your organisation financed?
a. Public funding.
b. Donations.
c. Income from clients. 


\section{Regional/local organisation}

9. Which are the main sources of donated food for your organisation?
a. Food producers.
b. Wholesalers.
c. Retail shops.
d. National food banks.

10. Does your organisation receive surplus food from national food banks?
a. Yes.
b. No.

11. Does your organisation have agreements with donors (retail, food producers, wholesalers, etc.) regionally/locally?
a. Yes.
b. No.

12. Do you collaborate with other redistribution organisations in your region?
a. Yes.
b. No.

13. Does your organisation compete with other organisations in your region for surplus food
a. Yes.
b. No.

14. How is your organisation financed?
a. Public funding.
b. Donations.
c. Income from clients. 


\section{Quality assurance}

15. Is your organisation approved as a food business operator?
a. No.
b. We are in the process of being approved.
c. Yes, approved in (specify year).

16. Do you have a Quality Assurance (QA) system for your organisation?
a. No.
b. We are in the process of being approved.
c. Yes, established in: (please specify year).

17. Is the Quality Assurance (QA) system based in standards for food hygiene, such as, e.g. BRC (British Retail Consortium)?
a. No.
b. Yes, based in: (please specify standard).

18. Is it possible to get a copy of the Quality Assurance (QA) documentation of your organisation?
a. Yes.
b. No.

\section{Registration and tracing}

19. Do you register food received from donors?
a. No.
b. Yes, by electronic registration.
c. Yes, by manual registration.

20. What kind of information do you register for the food that has been donated for redistribution? (Yes/No)
a. Type of food.
b. Amount of food per donation.
c. From which donor.
d. Time to expiry date. 
21. Do you register (Yes/No/only as an estimate)?

a. Number of meals served per day?

b. Clients served per day?

c. Number of food bags given away per day?

22. Which types of informations are being requested from your operations, by food safety authorities, stakeholders (donors, municipalities, financing organisations etc.)?

a. None.

b. Other (please specify).

23. Is your organisation able to trace surplus food from donors to the point of serving clients/giving away food bags?

a. No.

b. Yes (please specify how this is done).

24. Do you have a written description of your procedures for tracing/registration, and would you be willing to share this with us?

a. Yes.

b. No.

\section{Regulations and control - contact with authorities}

25 . Has regulations of redistribution been clearly stated to your organisation by food safety authorities?

a. Yes.

b. No.

26. Is redistribution being limited (Yes/No/Not sure)

a. By too strict regulations?

b. By too strong control regimes?

c. By lack of clear regulations and uncertainty about legality of operations? 
27. Are you regularly being controlled by food safety authorities?

a. No.

b. Yes (please specify when was the last time, and which remarks you received from the control).

28. What level of authorities and regulations impose the majority of restrictions?
a. Regional/local level.
b. National level.
c. They both impose the same degree of restrictions.

29. Does your organisation have a certification or approval from food safety authorities?
a. Yes.
b. No.

30. Is it possible to get a copy of the document?
a. Yes.
b. No.

Thank you very much for taking time to participate in this survey! 
Nordic Council of Ministers

Ved Stranden 18

DK-1061 Copenhagen K

www.norden.org

\section{Food Redistribution in the Nordic Region}

The Nordic Food Redistribution Project investigates food waste reduction through the redistribution of surplus food. The project goal is to increase and improve redistribution activities from donors to food banks and charity organisations in order to enhance both environmental and social sustainability in the Nordic region. The phase II report proposes best practice models concerning legislation, organisation, quality assurance and registration of food. Report recommendations are addressed at redistribution and food-serving actors, donors and authorities and focus on how to improve the quality of redistributed food, how to enhance collaboration between the various actors as well as how to prioritize and secure funding for redistribution activities. The report is part of the Nordic Prime Ministers' green growth initiative: “The Nordic Region leading in green growth".

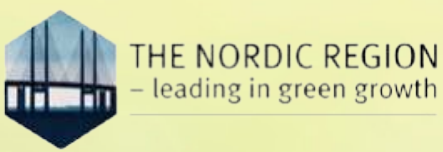

TemaNord 2016:502

ISBN 978-92-893-4447-0 (PRINT)

ISBN 978-92-893-4449-4 (PDF)

ISBN 978-92-893-4448-7 (EPUB)

ISSN 0908-6692

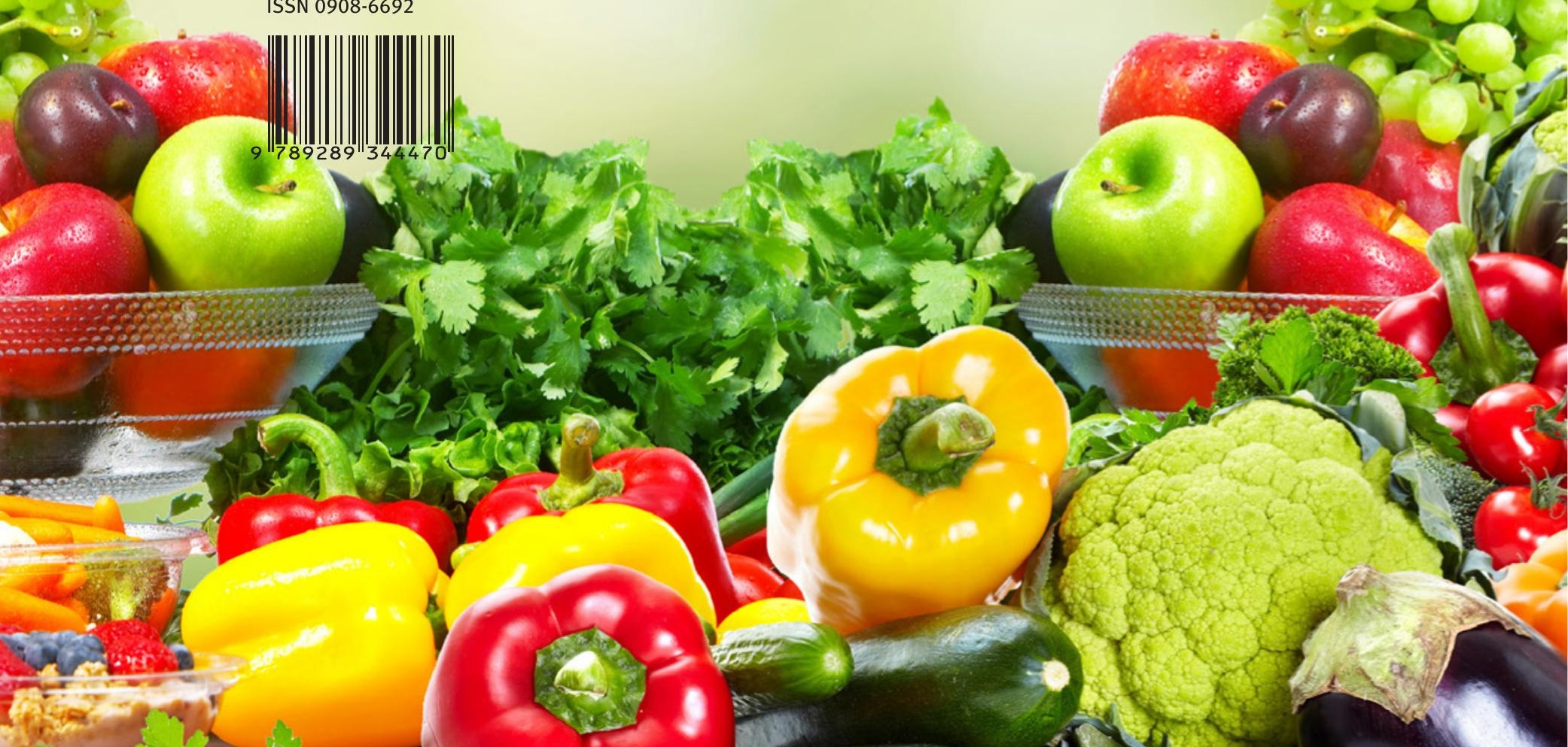

